\title{
Antioxidant Activity and Bio-Accessibility of Polyphenols in Black Carrot (Daucus carota L. ssp. sativus var. atrorubens Alef.) and Two Derived Products during Simulated Gastrointestinal Digestion and Colonic Fermentation
}

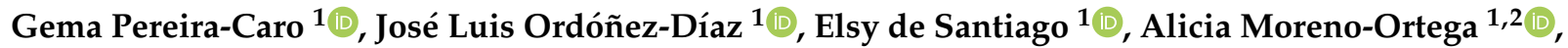 \\ Salud Cáceres-Jiménez ${ }^{1}$, Mónica Sánchez-Parra ${ }^{1}$, Francisco Javier Roldán-Guerra ${ }^{1}$ (D), Víctor Ortiz-Somovilla ${ }^{1}$ (D) \\ and José Manuel Moreno-Rojas 1,*(D) \\ 1 Department of Food Science and Health, Andalusian Institute of Agricultural and Fisheries Research and 7 \\ Training (IFAPA), Alameda del Obispo, Avda. Menéndez-Pidal, s/n, 14004 Córdoba, Spain; \\ mariag.pereira@juntadeandalucia.es (G.P.-C.); josel.ordonez@juntadeandalucia.es (J.L.O.-D.); \\ elsyg.santiago@juntadeandalucia.es (E.d.S.); t22moora@uco.es (A.M.-O.); saludcaceres@gmail.com (S.C.-J.); \\ monica.sanchez.parra@juntadeandalucia.es (M.S.-P.); franjaviroldan@gmail.com (F.J.R.-G.); \\ victor.ortiz@juntadeandalucia.es (V.O.-S.) \\ check for \\ updates \\ Citation: Pereira-Caro, G.; \\ Ordóñez-Díaz, J.L.; de Santiago, E.; \\ 2 Departamento de Bromatología y Tecnología de los Alimentos, Campus Rabanales, Ed. Darwin-anexo 9 \\ Universidad de Córdoba, 14071 Córdoba, Spain \\ * Correspondence: josem.moreno.rojas@juntadeandalucia.es
}

Moreno-Ortega, A.; Cáceres-Jiménez,

S.; Sánchez-Parra, M.; Roldán-Guerra

F.J.; Ortiz-Somovilla, V.;

Moreno-Rojas, J.M. Antioxidant Activity and Bio-Accessibility of

Polyphenols in Black Carrot (Daucus

carota L. ssp. sativus var. atrorubens

Alef.) and Two Derived Products during Simulated Gastrointestinal Digestion and Colonic Fermentation. Foods 2021, 10, 457. https://doi.org/ $10.3390 /$ foods 10020457

Academic Editor: Michael Netzel

Received: 30 December 2020

Accepted: 17 February 2021

Published: 19 February 2021

Publisher's Note: MDPI stays neutral with regard to jurisdictional claims in published maps and institutional affiliations.

Copyright: (c) 2021 by the authors Licensee MDPI, Basel, Switzerland This article is an open access article distributed under the terms and conditions of the Creative Commons Attribution (CC BY) license (https:// creativecommons.org/licenses/by/ $4.0 /)$
Abstract: Black carrot has been attracting increasing thanks to its high bioactive compound content. This study presents the polyphenol bio-accessibility of black carrot and two derived products (black carrot snack (BC snack) and black carrot seasoning (BC seasoning)) after in vitro gastrointestinal digestion and colonic fermentation. Additionally, antioxidant activity was measured by 2,2'-azinobis-(3-ethylbenzothiazoline-6-sulphonic acid) diammonium salt (ABTS), 1,1-diphenyl-2picryl-hydrazyl (DPPH) and oxygen radical absorbance capacity (ORAC) assays. Nine flavonoids and eight anthocyanins were determined by ultra high-performance liquid chromatography high resolution mass spectrometry (UHPLC-HRMS) analysis, the predominant compounds being the hydroxycinnamic acids 3-O-feruloylquinic acid, 4-O-feruloylquinic acid and chlorogenic acid. The BC snack $(108 \mu \mathrm{mol} / \mathrm{g}$ DW) presented the highest total polyphenol content, followed by BC seasoning (53 $\mathrm{mol} / \mathrm{g} \mathrm{DW})$ and black carrot $(11.4 \mu \mathrm{mol} / \mathrm{g}$ DW). The main polyphenols still bio-accessible after in vitro digestion were the hydroxycinnamic acids, with mean recovery rates of $113 \%$ for black carrot, $69 \%$ for BC snack and $81 \%$ for BC seasoning. The incubation of black carrot and its derived products with human faecal bacterial resulted in the complete degradation of anthocyanins and in the formation of mainly 3-(4'-hydroxyphenyl)propanoic acid as the major catabolic event. In conclusion, our results suggest that the black carrot matrix impacts significantly affects the bio-accessibility of polyphenols and, therefore, their potential health benefits.

Keywords: flavonoids; anthocyanins; phenolic acids; in vitro digestion; antioxidant activity; derived products; microbial metabolites

\section{Introduction}

Black carrot (Daucus carota ssp. satious var. atrorubens Alef.), also known as purple carrot, originated from countries such as Turkey, Afghanistan, Egypt, Pakistan, India and the Far East [1]. Although orange carrots are more common, the consumption of black carrots is currently increasing in Western Europe due to their benefits in human health. They present antioxidant, anti-proliferative and anti-inflammatory properties [2,3], which have been associated with their content of bioactive compounds, which are significantly related to antioxidant capacity [4-6]. Black carrot is characterized by an intense purple 
colour, which is attributed to its unique profile in specific water-soluble pigments, namely anthocyanins. The main anthocyanins in black carrots are acylated cyanidin derivatives such as cyanidin-3-feruloyl-xylosyl-glucosyl-galactoside and cyanidin-3-sinapoyl-xylosylglucosyl-galactoside [7-12], which have been shown to possess anticancer, antidiabetic and cardiovascular properties. Besides anthocyanins, black carrots also contain significant amounts of phenolic acids, including caffeoylquinic, chlorogenic, caffeic, sinapic, ferulic and coumaric acids [7,13-15].

Bioavailability is one of the factors that determine the health-promoting properties of black carrot phytochemicals. During gastrointestinal digestion, compounds may be degraded in the small intestine, or reach the colon and be metabolized by the human microbiota [16,17]. In vitro methods simulating digestion processes are widely used to study the release of compounds with the potential to be present in the intestinal brush border and be absorbed [18-20]. The bio-accessibility of bioactive compounds depends on their structure and binding to the food matrix.

The amount of (poly)phenolic compounds and anthocyanins in raw carrots has been reported to decrease after simulated gastrointestinal digestion [21,22]. Additionally, a decrease was found in antioxidant activity in raw black carrots after both gastric and intestinal conditions. In other studies [23,24], most of the anthocyanins in raw black carrots remained stable during gastric digestion. However, after the intestinal phase, their content drastically decreased.

In recent years, the number of new products from functional foods has increased due to their bioactive compound content. Black carrots have been used as a natural dye agent thanks to their high content of anthocyanins, which are responsible for their colour [25]. Black carrots are also processed by the food industry and consumed as soft drinks, dried snacks, juices, jellies, jams and marmalades [1]. However, during food processing, different physical and biological factors such as temperature and storage may have an effect on these bioactive compounds [26]. Kamiloglu et al. 2015 [21] reported a significant decrease in total phenolic compounds, anthocyanins and phenolic acids in jam and marmalade processed from black carrots, compared to the raw material.

Bio-accessibility studies into jam and marmalade produced from black carrots reported significant decreases in their (poly)phenol content and their antioxidant capacity after in vitro gastrointestinal digestion [27]. On the other hand, the total (poly)phenolic compound content in black carrot juice increased after simulated gastrointestinal digestion [28]. Studies into the bio-accessibility of black carrots and their derived products are very limited. Therefore, the main objective of this study was to evaluate the bio-accessibility of (poly)phenolic compounds after in vitro digestion and colonic fermentation, and to determine the antioxidant activity of black carrot and two derived products (black carrot snacks and black carrot seasoning) before and after in vitro gastrointestinal digestion.

\section{Materials and Methods}

\subsection{Chemicals}

HPLC-grade methanol $(\mathrm{MeOH})$, acetone and potassium hydroxide were acquired from Panreac Applichem ITW Reagents (Darmstadt, Germany); sodium chloride and magnesium chloride hexahydrate were purchased from Fisher Scientific (Madrid, Spain); 6-hydroxy-2,5,7,8-tetramethylchroman-2-carboxylic acid (Trolox), fluorescein, 2,2'-azobis(2amidinopropane)dihydrochloride (AAPH), 2,2'-azinobis-(3-ethylbenzothiazoline-6-sulphonic acid) diammonium salt (ABTS), sodium bicarbonate and ammonium carbonate were supplied by Sigma-Aldrich (Madrid, Spain); and potassium dihydrogen phosphate, sodium hydrogen carbonate, magnesium sulfate monohydrate and potassium hydrogen phosphate were obtained from VWR International Eurolab (Barcelona, Spain). Yeast extracts, peptone, tween 80, hemin, vitamin K, L-cysteine hydrochloride monohydrate, resazurin redox indicator and calcium chloride were acquired from Sigma-Aldrich (Madrid, Spain). $\alpha-$ Amylase from human saliva (300-1500 U/mg protein), pepsin (3.2-4.5 U/mg protein), pancreatin from porcine pancreas $(4 \times$ UPS), bile salts and calcium chloride were purchased 
from Sigma-Aldrich (Madrid, Spain). Reference standard compounds including 3, 4, 5trihydroxybenzoic acid (gallic acid), benzene-1,2-diol (catechol), 3,4-dihydroxybenzoic acid, 4-hydroxybenzoic acid, 4-hydroxy-3-methoxybenzoic acid (vanillic acid), chlorogenic acid, 3', $4^{\prime}$-dihydroxycinnamic acid (caffeic acid), 4'-hydroxy-3'-methoxycinnamic acid (ferulic acid), $4^{\prime}$-hydroxycinnamic acid ( $p$-coumaric acid) and delphinidin-3-glucoside were purchased from Sigma-Aldrich (Madrid, Spain). The acetonitrile and methanol were of liquid chromatography-mass spectrometry (LC-MS) grade. The name of the phenols used in this paper has been adjusted based on the recommendations by Kay et al. [29].

\subsection{Materials and Sample Preparation}

Black carrots (Daucus carota L. ssp. sativus var. atrorubens Alef.) and their derived products, including the black carrot snack (BC Snack) and the black carrot seasoning (BC Seasoning), were kindly provided by the company "Esali Alimentación, S.L." from Cuevas Bajas (Málaga, Spain). Both products derived from black carrots were obtained through a patented process involving freeze-drying techniques. This enables a porous texture to be obtained that facilitates the removal of water without the need for an increase in temperature, reducing drying time and preventing the oxidation of the product. The residual water content is less than $1 \%$. In addition, these derived products do not contain additives or preservatives. $\mathrm{BC}$ seasoning is obtained by grinding the $\mathrm{BC}$ snack. The fresh black carrots were washed, cut into small pieces and milled using a homogenizer (SAMMIC, Madrid, Spain), before being lyophilized in a freeze dryer ECO EVO (Tred Technology S.R.L., Ripalimosani, Italy), ground and stored at $-80^{\circ} \mathrm{C}$. The BC Snack was pooled and then ground and stored at $-80{ }^{\circ} \mathrm{C}$ until analysis.

\subsection{In Vitro Gastrointestinal Digestion}

An in vitro gastrointestinal digestion procedure was performed according to MorenoOrtega et al. 2020 [30]. Three steps simulated the oral, gastric and intestinal conditions. The details of the oral, gastric and intestinal phases are described in Moreno-Ortega et al. [30]. The whole process took place in a stirred water bath (Unitronic Reciprocating Shaking Bath, model 6032011, J.P. Selecta, Barcelona, Spain) at $37^{\circ} \mathrm{C}$ with $100 \mathrm{~mL}$ amber glass bottles containing $2 \mathrm{~g}$ of each sample in triplicate. During the oral phase, $2 \mathrm{~g}$ of lyophilized sample, $14 \mathrm{~mL}$ of simulated salivary fluids containing $250 \mu \mathrm{L}$ of $\alpha$-amylase $(1.3 \mathrm{mg} / \mathrm{mL}), 0.1 \mathrm{~mL}$ of $0.3 \mathrm{M} \mathrm{CaCl}_{2}$ and $5.65 \mathrm{~mL}$ of distilled water were shaken at $37^{\circ} \mathrm{C}$ for $5 \mathrm{~min}$. Then, the $\mathrm{pH}$ was adjusted to 3 using $1 \mathrm{M} \mathrm{HCl}$. A total of $15 \mathrm{~mL}$ of simulated gastric fluids was added to the samples, together with $1.19 \mathrm{~mL}$ of pepsin $(0.1 \mathrm{~g} / \mathrm{mL}), 0.01 \mathrm{~mL}$ of $0.3 \mathrm{M} \mathrm{CaCl}_{2}$ and $3.8 \mathrm{~mL}$ of distilled water. The mixture was incubated at $37^{\circ} \mathrm{C}$ for $120 \mathrm{~min}$. Finally, for the intestinal phase, $22 \mathrm{~mL}$ of simulated intestinal fluids were added to the samples, together with $10 \mathrm{~mL}$ of pancreatin solution $(8 \mathrm{mg} / \mathrm{mL}), 5 \mathrm{~mL}$ of bile salts $(25 \mathrm{mg} / \mathrm{mL}), 0.08 \mathrm{~mL}$ of $0.3 \mathrm{M} \mathrm{CaCl}_{2}$ and $9.92 \mathrm{~mL}$ of distilled water. Then, $1 \mathrm{M} \mathrm{NaOH}$ solution was used to adjust the $\mathrm{pH}$ to 7 . The mixture was incubated for $120 \mathrm{~min}$ at $37^{\circ} \mathrm{C}$. Samples were taken before (BOD) and after oral digestion (AOD) and after gastric (AGD) and intestinal digestion (AID) in individual experiments. These samples were lyophilized and stored at $-80^{\circ} \mathrm{C}$. The bio-accessibility index was calculated as the compound concentration after simulated gastrointestinal digestion divided by the compound concentration in non-digested samples.

\subsection{In Vitro Colonic Fermentation}

The freeze-dried digested samples were subjected individually to in vitro fermentation to simulate the conditions in the colon following the method described by De Santiago et al. [20] and adapted to our laboratory. Details of the composition of the growth medium are described in De Santiago et al. [20]. The human faecal samples were obtained from three healthy non-smoking volunteers (three males aged between 22 and 34 and with BMIs between 20.5 and 25.4) who had not consumed antibiotics for at least 6 months prior to the study. The volunteers followed a low polyphenol diet for $48 \mathrm{~h}$ before the faecal sample collection. The samples were collected by the donors in plastic tubes containing an 
AnaeroGen sachet (Oxoid Ltd., Cambridge, UK) to maintain anaerobic conditions during transportation and were processed within $30 \mathrm{~min}$ of passage. Faecal slurry was prepared by homogenizing the faeces in pre-reduced phosphate buffered saline (PBS). The temperature of the incubation was set to $37^{\circ} \mathrm{C}$ using a Unitronic OR circulating water-bath (JP Selecta, Abrera, Spain) and the fermentation bottles were inoculated with faecal slurry $(10 \% w / v$ of fresh human faeces) for a period of $48 \mathrm{~h}$. After the addition of the liophylized digested BC, BC Snack and BC Seasoning samples ( $2 \mathrm{~g})$, the bottles were purged with oxygen free nitrogen (OFN) and sealed airtight and the anaerobiotic conditions were maintained by using a continuous OFN flow. Aliquots $(1 \mathrm{~mL})$ of faecal suspensions were taken after 0,4 , 8,24 and $48 \mathrm{~h}$. The samples were centrifuged at $13,500 \mathrm{rpm}$ at $4{ }^{\circ} \mathrm{C}$ for $10 \mathrm{~min}$ and stored immediately at $-80^{\circ} \mathrm{C}$ until analysis.

\subsection{Extraction of Polyphenols from Digested Samples and from Faecal Incubates}

The extraction of polyphenols from the in vitro digested samples and the faecal samples was adapted from Ordóñez-Díaz et al. [31] with some modifications. For the in vitro digested samples, $0.25 \mathrm{~g}$ of lyophilized sample was homogenized with $1 \mathrm{~mL}$ of a methanol/acidified water mixture $(80: 20, v / v)$ with $0.1 \%$ formic acid. The samples were centrifuged at $5000 \mathrm{rpm}$ for $10 \mathrm{~min}$ at $4{ }^{\circ} \mathrm{C}$, and supernatants were collected. The pellet was re-extracted with $1 \mathrm{~mL}$ of the same solvent as described above. All the supernatants were pooled to a final volume of $2 \mathrm{~mL}$. For the fermented black carrot samples, $0.5 \mathrm{~mL}$ of faecal incubates were extracted using $0.5 \mathrm{~mL}$ of $0.1 \%$ formic acid in methanol/acidified water $(80: 20, v / v)$, vortexed and centrifuged at $5000 \mathrm{rpm}$ for $10 \mathrm{~min}$ at $4{ }^{\circ} \mathrm{C}$, and supernatants were collected.

\subsection{Antioxidant Capacity Measurements}

\subsubsection{ABST Assay}

Free radical scavenging activity was measured using the ABTS discoloration method [32] with some modifications [33]. Briefly, the ABTS radical cation $\left(\mathrm{ABTS}^{+}\right)$was produced by reacting ABTS with $2.45 \mathrm{mM}$ of potassium persulfate solution and allowing the mixture to stand in the dark at room temperature for $12-16 \mathrm{~h}$ before use. The $\mathrm{ABTS}^{+}$solution was diluted with methanol to obtain a final absorbance of $0.8 \pm 0.02$ at $730 \mathrm{~nm}$. Fresh ABTS ${ }^{+}$ solution was prepared for each assay and day. Digested extracts $(10 \mu \mathrm{L})$ were added to $190 \mu \mathrm{L}$ of $\mathrm{ABTS}^{+}{ }^{+}$solution in a 96-well microplate and the absorbance was measured every $20 \mathrm{~s}$ at $30^{\circ} \mathrm{C}$ for $6 \mathrm{~min}$, using a Synergy HTX Multi-Mode Microplate Reader (Biotek Instruments, Winooski, VT, USA). Methanol or Trolox were used as a blank or as standard. The percentage inhibition of absorbance versus time was plotted and the area below the curve (0-360 s) was calculated. Methanolic solutions of a known concentration of Trolox were used for calibration ( 0.1 to $0.8 \mathrm{mM})$. The antioxidant activity was expressed as $\mu \mathrm{mol}$ of Trolox equivalents per gram of dry sample ( $\mu \mathrm{mol} \mathrm{TE} / \mathrm{g} D W)$. Each value is the average of three measurements.

\subsubsection{DPPH Assay}

Free radical DPPH (1,1-diphenyl-2-picryl-hydrazyl) scavenging capacity was determined by using the methods previously described by Sánchez-Moreno et al. [34]. Briefly, digested extracts $(10 \mu \mathrm{L})$ were added to $190 \mu \mathrm{L}$ of DPPH $0.35 \mathrm{mg} / \mathrm{mL}$ prepared daily in a 96-well microplate. The absorbance was measured at $515 \mathrm{~nm}$ every minute at $30^{\circ} \mathrm{C}$ for $60 \mathrm{~min}$, using a Synergy HTX Multi-Mode Microplate Reader (Biotek Instruments, Winooski, VT, USA). Methanol or Trolox were used as a blank or as standard. The percentage inhibition of absorbance versus time was plotted and the area below the curve (0-60 min) was calculated. Methanolic solutions of a known concentration of Trolox were used for calibration ( 0.1 to $1 \mathrm{mM}$ ). The antioxidant activity was expressed as $\mu \mathrm{mol}$ of Trolox equivalents per gram of dry sample ( $\mu \mathrm{mol} \mathrm{TE} / \mathrm{g} D W)$. Each value is the average of three measurements. 


\subsubsection{Oxygen Radical Absorbance Capacity (ORAC) Assay}

Oxygen radical scavenging activity was measured by the ORAC assay according to the method previously published by Huang et al. [35] and modified by Pereira-Caro et al., [33]. Briefly, $25 \mu \mathrm{L}$ of either Trolox, digested extract or methanol as a blank were added to a 96-well microplate followed by the addition of $150 \mu \mathrm{L}$ of fluorescein working solution $\left(8.5 \times 10^{-5} \mathrm{mM}\right)$ prepared in $75 \mathrm{mM}$ phosphate buffer $(\mathrm{pH}$ 7.4). The fluorescence was recorded every two minutes for $120 \mathrm{~min}$ at 485 and $528 \mathrm{~nm}$ after the addition of $30 \mu \mathrm{L}$ of AAPH $(153 \mathrm{mM}$ ) as peroxyl radical generator. The microplate reader (Synergy HTX Multi-Mode Microplate Reader (Biotek Instruments, Winooski, VT, USA)) was used. The final results were calculated according to Pereira-Caro et al. [33]. ORAC values are expressed as mmol Trolox equivalents per gram of dry sample ( $\mu \mathrm{mol} \mathrm{TE} / \mathrm{g} \mathrm{DW})$.

\subsection{UHPLC-HRMS Polyphenol Analysis}

The polyphenols (flavonoids and anthocyanins) in the extracted samples of the in vitro digested BC, BC Snack and BC Seasoning, and in the faecal incubation samples were identified and quantified using a UHPLC-HRMS mass spectrometer system (Thermo Scientific, San José, CA, USA) consisting of a UHPLC pump, a PDA detector scanning from 200 to $600 \mathrm{~nm}$, and an autosampler operating at $4{ }^{\circ} \mathrm{C}$ (ThermoFisher Scientific, San Jose, CA, USA).

\subsubsection{Analysis of Flavonoids}

The flavonoids were separated on a Kinetex C18 $(150 \times 4.6 \mathrm{~mm}$ i. d. $5 \mu \mathrm{m} 100 \mathrm{~A}$ (Phenomenex, UK)) preceded by a guard pre-column of the same stationary phase and maintained at $40{ }^{\circ} \mathrm{C}$. The mobile phases, A: acidified water $0.1 \%$ formic acid and B: acetonitrile, were pumped at a flow rate of $1.0 \mathrm{~mL} \mathrm{~min}^{-1}$ with a $35 \mathrm{~min}$ gradient starting at $3 \% \mathrm{~B}$ and maintained for $5 \mathrm{~min}$, then rising to $60 \% \mathrm{~B}$ in $30 \mathrm{~min}$, maintained for $3 \mathrm{~min}$ and then rising to $85 \% \mathrm{~B}$ in $10 \mathrm{~min}$. Next, the column was equilibrated to the previous conditions within $10 \mathrm{~min}$. After passing through the flow cell of the photo diode array (PDA) detector part of the column, the eluate $(0.2 \mathrm{~mL} / \mathrm{min})$ entered an Exactive Orbitrap mass spectrometer (MS) (Thermo Scientific, San José, CA, USA) fitted with a heated electrospray ionization probe (HESI) operating in negative ionization mode for the determination of polyphenols. Full scans were recorded in $\mathrm{m} / \mathrm{z}$ range from 100 to 1200 with a resolution of $50.000 \mathrm{~Hz}$ and with a full automatic gain control (AGC) target of 100,000 charges, using 2 micro-scans. Analyses were also based on scans with in-source collision-induced dissociation (CID) at $25.0 \mathrm{eV}$. The experimental conditions of the MS with HESI in negative ionization mode were a capillary temperature of $320^{\circ} \mathrm{C}$, a heater temperature of $150{ }^{\circ} \mathrm{C}$, a sheath gas flow of 35 units, an auxiliary gas flow of 10 units, and a spray voltage of $4.0 \mathrm{kv}$. Data were acquired and processed using the Xcalibur 3.0 software.

\subsubsection{Analysis of Anthocyanins}

The separations of anthocyanins in the digested and fermented BC, BC Snack and BC Seasoning extracts were based on the protocol previously described by Hornedo-Ortega et al. [36] with some modifications. Briefly, the separation was based on a Zorbax SB-18 column $(2.1 \times 100 \mathrm{~mm}$ d.i. $1.8 \mu \mathrm{m})$ (equipped with a Zorbax SB-18 $1.8 \mu \mathrm{m}$ van-guard pre-column) (Agilent, Madrid, Spain) maintained at $40{ }^{\circ} \mathrm{C}$ and eluted using two mobile phases: A: deionized water with $5 \%$ formic acid; and B: acetonitrile with $5 \%$ formic acid, over the course of $15 \mathrm{~min}$ at $0.3 \mathrm{~mL} \mathrm{~min}{ }^{-1}$. The gradient started at $5 \% \mathrm{~B}$, was maintained for $2 \mathrm{~min}$ and then rose to $100 \% \mathrm{~B}$ in $10 \mathrm{~min}$. These conditions were maintained for $2 \mathrm{~min}$ and after $1 \mathrm{~min}$ returned to $5 \% \mathrm{~B}$, then maintained for $4 \mathrm{~min}$ to equilibrate the column to the initial conditions. After passing through the flow cell of the PDA detector, the column eluate went directly to an Exactive Orbitrap mass spectrometer (Thermo Scientific, San José, CA, USA) fitted with a heated electrospray ionization probe (HESI) operating in positive ionization mode for the determination of anthocyanins. Full scans were recorded in $\mathrm{m} / \mathrm{z}$ range from 100 to 1000 with a resolution of $50,000 \mathrm{~Hz}$ and with a full AGC target of 
100000 charges, using 2 micro-scans. The analyses were also based on scans with in-source collision induced dissociation (CID) at $25.0 \mathrm{eV}$. The experimental conditions of the MS with HESI in positive ionization mode were capillary temperature of $300{ }^{\circ} \mathrm{C}$, heater temperature of $60{ }^{\circ} \mathrm{C}$, a sheath gas flow of 20 units, an auxiliary gas flow of 2 units, and a spray voltage of $4.0 \mathrm{kv}$. Data were acquired and processed using the Xcalibur 3.0 software.

\subsubsection{Identification and Quantification of Flavonoids and Anthocyanins}

The targeted identification of phenolic compounds and anthocyanins was achieved as follows: (i) by comparing the exact mass and the retention time with available standards; and (ii) in the absence of standards, compounds were tentatively identified by comparing the theoretical exact mass of the molecular ion with the measured accurate mass of the molecular ion and searched against metabolite databases including Metlin, Phenol Explorer and more general chemical databases such as PubChem and ChemSpider. Metabolites having molecular masses within the pre-specified tolerance ( $\leq 5 \mathrm{ppm})$ of the query masses were retrieved from these databases. Identifications were categorized according to the Metabolite Standards Initiative Metabolite Identification (MSIMI) levels [37]. The phenolic compounds and anthocyanins were quantified by selecting the theoretical exact mass of the molecular ion by reference to standard curves. In the absence of reference compounds, they were quantified by reference to the calibration curve of a closely related parent compound. The limits of detection (LOD) and quantification (LOQ) varied from 0.001 to $0.05 \mathrm{ng} / \mu \mathrm{L}$ and from 0.03 to $0.12 \mathrm{ng} / \mu \mathrm{L}$, respectively. LOD and LOQ were calculated as previously reported [38].

\subsection{Statistical Analysis}

A one-way ANOVA and Tukey's honestly significant difference (HSD) post-hoc tests were applied to identify the differences among the different phases of the in vitro gastrointestinal digestion and faecal fermentation using $\mathrm{R}$ software (v. 3.6.3, R Core Team, Vienna, Austria).

\section{Results and Discussion}

3.1. Effect of In Vitro Digestion of Black Carrot and Its Derived Products on Polyphenol Stability and Antioxidant Capacity

Table S1 and Figures S1 and S2 (in Supporting Information) show the HPLC-HRMS characteristics and HPLC-HRMS profiles of the identified compounds. A total of 21 polyphenols were identified in black carrot and its derived products, including four hydroxybenzoic acids, seven hydroxycinnamic acids, two flavonols and eight anthocyanins. Figures 1 and 2 show the chemical structures of the quantified phenolic compounds and anthocyanins in the black carrot, BC snack and BC seasoning samples, respectively. Tables 1 and 2 provide information about the quantities of 17 polyphenols identified, including nine phenolic compounds and eight anthocyanins in black carrot and its derived products. The remaining compounds not quantified were detected in trace amounts.

Among the phenolic compounds, hydroxycinnamic acid derivatives such as chorogenic acid (2.52 $\mu \mathrm{mol} / \mathrm{g} \mathrm{DW})$, 3-O-feruoylquinic acid $(4.01 \mu \mathrm{mol} / \mathrm{g} \mathrm{DW})$ and $p$-coumaroylquinic acid $(4.41 \mu \mathrm{mol} / \mathrm{g} \mathrm{DW})$ were the main polyphenols determined in black carrot, representing $95.8 \%$ of the total polyphenol content, which is in accordance with previously published data [1,7]. Meanwhile, the major polyphenol in the BC snack and BC seasoning were chlorogenic acid $(6.65 \mu \mathrm{mol} / \mathrm{g}$ DW and $3.8 \mu \mathrm{mol} / \mathrm{g}$ DW, respectively), 3-O-feruloylquinic acid $(81.31 \mu \mathrm{mol} / \mathrm{g}$ DW and $28.04 \mu \mathrm{mol} / \mathrm{g} \mathrm{DW}$, respectively) and 4O-feruloylquinic acid (11.62 $\mu \mathrm{mol} / \mathrm{g} \mathrm{DW}$ and $13.39 \mu \mathrm{mol} / \mathrm{g} \mathrm{DW}$, respectively), which comprised $92.3 \%$ and $86.0 \%$ of the total polyphenols in the BC snack and BC seasoning, respectively. The remaining polyphenols quantified in the black carrot and its derived products, occurring as minor compounds, were 4-hydroxybenzoic acid, 3,4-dihydroxybenzoic acid, $p$-coumaric acid, caffeic acid and ferulic acid. Overall, the total polyphenol content in the BC snack $(107.88 \mu \mathrm{mol} / \mathrm{g}$ DW) is markedly higher than that in the BC season- 
ing $(52.56 \mu \mathrm{mol} / \mathrm{g}$ DW). The black carrot presented the lowest amount of polyphenols $(11.42 \mu \mathrm{mol} / \mathrm{g}$ DW). These results are in keeping with the antioxidant capacity determined by the ABTS, DPPH and ORAC assays (Figure 3), where the BC snack showed a significantly higher antioxidant capacity than the BC seasoning, followed by black carrot, according to the three methods used. Regarding anthocyanins, cyanidin-3-xylosyl-feruloylglucosyl-galactoside, followed by cyanidin-3-xylosyl-sinapoyl-glucosyl-galactoside and cyanidin-3-xylosyl-coumaroyl-glucosyl-galactoside were the main ones quantified in the black carrot, BC snack and BC seasoning, accounting for 95.2, 91.3 and $95.4 \%$, respectively. This anthocyanin profile, with sinapic, ferulic and coumaric acid as the predominant black carrot anthocyanins, is in line with studies in the literature, which also found acylated cyanidins $[13,21]$. The remaining anthocyanins consisted of five minor compounds, including cyanidin-3-xylosyl-galactoside, pelargonidin-3-sambiburoside, pelargonidin-3,5diglucoside, cyanidin-3-xylosyl-glucosyl-galactoside and delphinidin-3-glucoside. Comparing the samples, the black carrot presented the highest total anthocyanin concentration of $194.8 \mathrm{nmol} / \mathrm{g}$ DW, while the BC snack and BC seasoning contained 8.2 and $5.2 \mathrm{nmol} / \mathrm{g}$ DW, respectively.
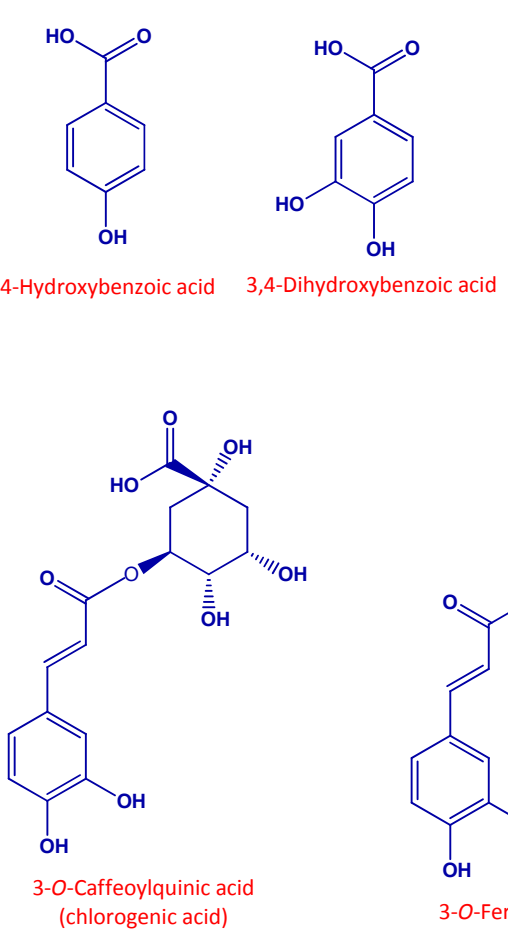

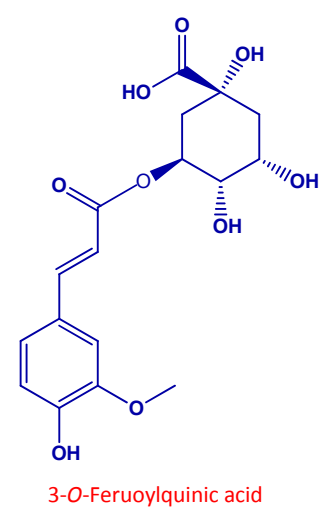

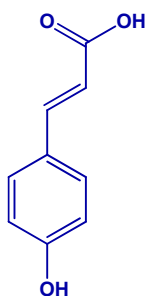

4-Hydroxycinnamic acid ( $p$-Coumaric acid)

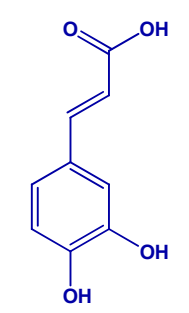

3,4-Dihydroxycinnamic (Caffeic acid)

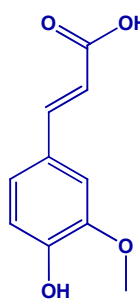

-methoxycinnamic acid (Ferulic acid)
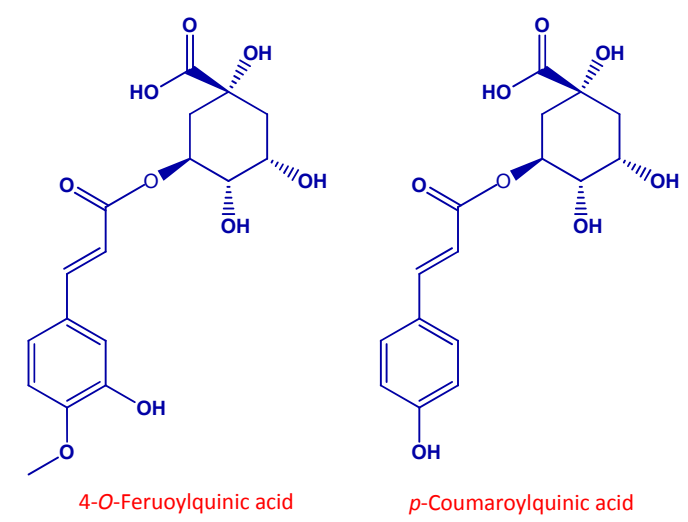

Figure 1. Chemical structure of the main phenolic compounds quantified in black carrot samples and derived products.

The variation in the total anthocyanin and polyphenol content and in the individual anthocyanin and polyphenol profiles in black carrot and its derived products may result from the elaboration process. Indeed, several factors, such as changes in the $\mathrm{pH}$, the presence of oxygen, elevated temperatures and the drying process, may affect the final concentration of polyphenols and anthocyanins in the derived products [39].

The in vitro digestion procedure indicated which compounds remain after gastrointestinal conditions and are likely to reach the colon, where they will be transformed by the resident bacteria. Tables 1 and 2 show the respective stability of the polyphenols and anthocyanins in black carrot, BC snack and BC seasoning before (non-digested) and after oral, gastric and intestinal digestion. 
<smiles></smiles>

Cyanidin-3-xylosy-synapoyl-lglucosyl-galactoside

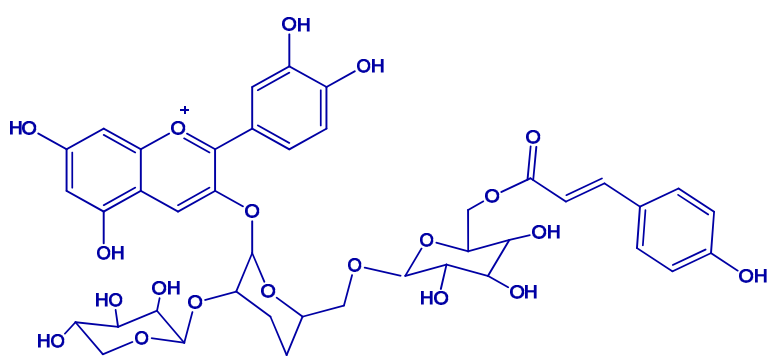

Cyanidin-3-xylosy-coumaroyl-glucosyl-galactoside<smiles></smiles>

Cyanidin-3-xylosy-feruoyl-lglucosyl-galactoside<smiles></smiles>

Cyanidin-3-xylosylglucosylgalactoside<smiles></smiles>

Cyanidin-3-xylosylgalactoside<smiles></smiles>

Pelargonidin-3-sambubiroside<smiles>COc1cc2cc(O)cc(O)c2cc1-c1cc(O)c(O)c(O)c1</smiles>

Delphinidin-3-O-glucoside<smiles></smiles>

Pelargonidin-3,5-diglucoside

Figure 2. Chemical structure of the main anthocyanins quantified in black carrot samples and derived products.

After oral digestion, the concentration of phenolic compounds, including 4-hydroxybenzoic acid, 3,4-dihydroxybenzoic acid, $p$-coumaric acid, caffeic acid and ferulic acid, significantly increased in the black carrot samples, with recovery rates between $118 \%-435 \%$. On the other hand, the hydroxycinnamic acids such as chlorogenic acid, 3-O-feruloylquinic acid, 4-O-feruloylquinic acid and $p$-coumaroyl-quinic acid were more unstable under the oral conditions, between $15.4 \%-84.6 \%$ remaining (Table 1 ). This can be explained by the hydrolysis of feruloyl-quinic and $p$-coumaroyl-quinic acid into ferulic acid and $p$-coumaric acid during the oral phase. The overall recovery of polyphenols after oral digestion was $6.7 \mu \mathrm{mol} / \mathrm{g} \mathrm{DW}$, representing $58.6 \%$ of the initial content. This value differs significantly from those obtained for the BC snack and BC seasoning, which showed an overall recovery of total polyphenols after oral digestion of $76.3 \%(82.3 \mu \mathrm{mol} / \mathrm{g} \mathrm{DW})$ and $75 \%(39.4 \mu \mathrm{mol} / \mathrm{g}$ DW), respectively. The decrease in polyphenols in both food matrices after oral digestion is mainly due to losses in specific compounds such as $p$-coumaric acid, chlorogenic acid, 
O-feruloyl-quinic acids, ferulic acid and $p$-coumaroyl-quinic acid (Table 1). Oral digestion seems to negatively affect the total concentration of polyphenols, this being more marked in the black carrot samples compared to the BC snack and BC seasoning. This behavior is also shown in the significant decrease in the antioxidant capacity after oral digestion of black carrot by ABTS, DPPH and ORAC measurements (Figure 3). In the case of the BC snack and BC seasoning, there was a significant decrease in the antioxidant activity after oral digestion, as measured by the ABTS and DPPH assays (with a 57\%-66\% of reduction). However, the antioxidant activity of the BC snack and BC seasoning was not affected significantly by the oral phase when this was measured by the ORAC assay $(13 \%-19 \%$ reduction). These differences in the trend of the results could be explained by the chemistry principles upon which the antioxidant assays are based [40]. In this regard, the ORAC assay measures peroxyl-radical scavenging with a more relevant significance, while the ABTS and DPPH involve large organic radicals that present steric hindrance [41]. The gastric conditions did not greatly alter the total concentration of polyphenols with regard to the oral digestion, with recoveries of $54.8 \%(6.3 \mu \mathrm{mol} / \mathrm{g} \mathrm{DW}), 79.6 \%(85.8 \mu \mathrm{mol} / \mathrm{g} \mathrm{DW})$ and $73.0 \%(38.4 \mu \mathrm{mol} / \mathrm{g}$ DW) for the black carrot, BC snack and BC seasoning, respectively. These results are in keeping with the antioxidant activity values, where there was no significant difference between the oral and gastric digestion phases by ABTS, DPPH and ORAC assays for the three food products. It is noteworthy that the concentration of hydroxycinnamate 4-O-feruloylquinic acid significantly increased after gastric digestion in the black carrot, with 4.1-fold increases compared to the non-digested samples, whereas this value remained stable in the BC snack and BC seasoning (Table 1). After intestinal digestion, the total polyphenol content in black carrot increased, from $6.26 \mu \mathrm{mol} / \mathrm{g} \mathrm{DW}$ to $12.9 \mathrm{mmol} / \mathrm{g}$ DW, with a mean bio-accessibility of $113 \%$. This pattern is also shown by the increase in the antioxidant capacity in the intestinal step in the black carrot samples, this increase being statistically significant by the ORAC assay. Regarding the BC snack and $\mathrm{BC}$ seasoning, the antioxidant capacity in the intestinal phase decreased by the ABTS and DPPH tests while the ORAC assay showed a similar antioxidant capacity for BC snack compared with the non-digested samples and a significant decrease for the $\mathrm{BC}$ seasoning samples. These differences can be explained by the difference in the chemistry of the three tests used, as stated above.

Table 1. Quantities ( $\mu \mathrm{mol} / \mathrm{g}$ DW) of polyphenols determined in black carrot, black carrot snack and black carrot seasoning before (non-digested) and after oral, gastric and intestinal in vitro digestion. Different letters within a column denote a significant difference $(p<0.05)$ as measured by one-way ANOVA followed by the Tukey honestly significant difference (HSD) post-hoc test. n.d.: not detected.

\begin{tabular}{|c|c|c|c|c|c|c|c|c|c|c|}
\hline & $\begin{array}{l}\text { 4- } \\
\text { Hydroxybenzoic } \\
\text { Acid }\end{array}$ & $\begin{array}{c}3,4- \\
\text { Dihydroxybenzoic } \\
\text { Acid }\end{array}$ & $\underset{\text { Acid }}{p \text {-Coumaric }}$ & Caffeic Acid & $\begin{array}{l}\text { Chlorogenic } \\
\text { Acid }\end{array}$ & $\begin{array}{l}\text { 3-O- } \\
\text { Feruloylquinic } \\
\text { Acid }\end{array}$ & $\begin{array}{l}\text { 4-O- } \\
\text { Feruloylquinic } \\
\text { Acid }\end{array}$ & Ferulic Acid & $\begin{array}{c}p- \\
\text { Coumaroyl } \\
\text { Quinic Acid }\end{array}$ & Total \\
\hline \multicolumn{11}{|c|}{ Black Carrot } \\
\hline Non-digested & $0.13 \pm 0.02^{c}$ & $0.22 \pm 0.04^{d}$ & $0.01 \pm 0.01^{b}$ & $0.02 \pm 0.01^{c}$ & $2.52 \pm 0.08^{\mathrm{a}}$ & $4.01 \pm 0.02^{\mathrm{a}}$ & $0.06 \pm 0.01^{\mathrm{c}}$ & $0.04 \pm 0.01^{b}$ & $4,41 \pm 0.8^{\mathrm{a}}$ & $11.4 \pm 0.3^{\mathrm{a}}$ \\
\hline Oral Digestion & $\begin{array}{c}0.37 \pm 0.01 \text { a } \\
297\end{array}$ & $\begin{array}{c}0.44 \pm 0.05^{c} \\
199\end{array}$ & $\begin{array}{c}0.03 \pm 0.01^{\mathrm{a}} \\
342\end{array}$ & $\begin{array}{c}0.09 \pm 0.01^{\mathrm{a}} \\
435\end{array}$ & $\begin{array}{c}0.39 \pm 0.03^{c} \\
15.4\end{array}$ & $\begin{array}{c}3.4 \pm 0.7^{b} \\
85\end{array}$ & $\begin{array}{c}\text { n.d. } \\
0\end{array}$ & $\begin{array}{c}0.05 \pm 0.01^{\mathrm{a}} \\
118\end{array}$ & $\begin{array}{c}1.93 \pm 0.02^{c} \\
44\end{array}$ & $\begin{array}{c}6.7 \pm 0.8^{b} \\
58.6\end{array}$ \\
\hline $\begin{array}{l}\text { Gastric } \\
\text { Digestion }\end{array}$ & $0.27 \pm 0.01^{b}$ & $0.65 \pm 0.01^{b}$ & $0.02 \pm 0.01^{b}$ & $0.03 \pm 0.01^{b}$ & $0.55 \pm 0.06^{\mathrm{b}}$ & $2.5 \pm 0.4^{\mathrm{c}}$ & $0.25 \pm 0.06^{\mathrm{b}}$ & $0.03 \pm 0.01^{\mathrm{c}}$ & $1.9 \pm 0.7^{\mathrm{c}}$ & $6.3 \pm 0.6^{\mathrm{b}}$ \\
\hline$\%$ & 212 & 297 & 190 & 135 & 21.8 & 63 & 405 & 65 & 44 & 54.8 \\
\hline $\begin{array}{l}\text { Intestinal } \\
\text { Digestion }\end{array}$ & $0.33 \pm 0.01^{\mathrm{a}}$ & $0.73 \pm 0.02^{\mathrm{a}}$ & $0.02 \pm 0.00^{b}$ & $0.04 \pm 0.00^{b}$ & $0.68 \pm 0.03^{b}$ & $4.08 \pm 0.04^{\mathrm{a}}$ & $4.5 \pm 0.2^{\mathrm{a}}$ & $0.05 \pm 0.01^{\mathrm{a}}$ & $2.44 \pm 0.03^{b}$ & $12.9 \pm 0.3^{a}$ \\
\hline$\%$ & 259 & 333 & 285 & 218 & 26.9 & 102 & 7231 & 136 & 55 & 113 \\
\hline \multicolumn{11}{|c|}{ Black Carrot Snack } \\
\hline Non-digested & $0.87 \pm 0.05^{c}$ & $3.2 \pm 0.1^{\mathrm{a}}$ & $0.03 \pm 0.01^{\mathrm{a}}$ & $0.27 \pm 0.04^{\mathrm{a}}$ & $6.6 \pm 0.2^{\mathrm{a}}$ & $81.3 \pm 0.7^{\mathrm{a}}$ & $11.6 \pm 0.8^{b}$ & $0.56 \pm 0.04^{a}$ & $3.34 \pm 0.03^{a}$ & $108 \pm 2^{a}$ \\
\hline Oral Digestion & $\begin{array}{c}1.30 \pm 0.09^{b} \\
149\end{array}$ & $\begin{array}{c}3.0 \pm 0.2^{\mathrm{a}} \\
92\end{array}$ & $\begin{array}{c}0.02 \pm 0.00^{\mathrm{a}} \\
74\end{array}$ & $0.25 \pm 0.02^{b}$ & $\begin{array}{c}5.3 \pm 0.4^{b} \\
80\end{array}$ & $\frac{60 \pm 11^{b}}{74}$ & $\begin{array}{l}9 \pm 1^{c} \\
79\end{array}$ & $\begin{array}{c}0.43 \pm 0.09^{c} \\
77\end{array}$ & $2.6 \frac{ \pm 0.6^{b}}{79}$ & $82 \pm 13^{b}$ \\
\hline $\begin{array}{l}\text { Gastric } \\
\text { Digestion }\end{array}$ & $2.0 \pm 0.1^{\mathrm{a}}$ & $2.8 \pm 0.0^{b}$ & n.d. & $0.2 \pm 0.0^{\mathrm{c}}$ & $4.6 \pm 0.1^{c}$ & $60 \pm 4^{\mathrm{b}}$ & $13 \pm 1^{\mathrm{a}}$ & $0.5 \pm 0.1^{b}$ & $3.1 \pm 0.1^{\mathrm{a}}$ & $85 \pm 5^{b}$ \\
\hline$\%$ & 230 & 87.6 & 0 & 91 & 69 & 74 & 109 & 81 & 93 & 80 \\
\hline $\begin{array}{l}\text { Intestinal } \\
\text { Digestion }\end{array}$ & $1.8 \pm 0.0^{\mathrm{a}}$ & $2.8 \pm 0.1^{b}$ & n.d. & $0.2 \pm 0.0^{c}$ & $4.5 \pm 0.1^{\mathrm{c}}$ & $51 \pm 2^{c}$ & $11.1 \pm 0.5^{b}$ & $0.5 \pm 0.0^{\mathrm{b}}$ & $2.7 \pm 0.8^{b}$ & $74 \pm 3^{c}$ \\
\hline$\%$ & 206 & 86 & 0 & 83 & 68 & 62 & 95 & 92 & 82 & 69 \\
\hline \multicolumn{11}{|c|}{ Black Carrot Seasoning } \\
\hline Non-digested & $2.14 \pm 0.05^{\mathrm{a}}$ & $2.8 \pm 0.2^{\mathrm{a}}$ & $0.01 \pm 0.00$ & $0.05 \pm 0.01$ & $3.80 \pm 0.08^{a}$ & $28 \pm 4^{\mathrm{a}}$ & $13.4 \pm 0.8^{\mathrm{b}}$ & $0.34 \pm 0.07^{\mathrm{a}}$ & $1.98 \pm 0.05^{\mathrm{a}}$ & $53 \pm 2^{a}$ \\
\hline Oral Digestion & $1.8 \pm 0.1^{b}$ & $\begin{array}{c}2.4 \pm 0.1^{b} \\
86\end{array}$ & $\begin{array}{c}0.01 \pm 0.00 \\
100\end{array}$ & $\begin{array}{c}0.05 \pm 0.01 \\
100\end{array}$ & $\begin{array}{c}3.1 \pm 0.8^{\mathrm{b}} \\
83\end{array}$ & $21 \pm 7^{b}$ & $\begin{array}{c}9.0 \pm 0.5^{c} \\
67\end{array}$ & $\begin{array}{c}0.22 \pm 0.01^{b} \\
66\end{array}$ & $\begin{array}{c}1.4 \pm 0.5^{b} \\
72\end{array}$ & $39 \pm 9^{b}$ \\
\hline $\begin{array}{l}\text { Gastric } \\
\text { Digestion }\end{array}$ & $1.9 \pm 0.6^{b}$ & $2.7 \pm 0.4 \mathrm{ab}$ & n.d. & n.d. & $2.3 \pm 0.4^{c}$ & $17 \pm 6^{c}$ & $13 \pm 1^{b}$ & $0.2 \pm 0.0^{\mathrm{b}}$ & $1.1 \pm 0.4^{\mathrm{c}}$ & $38 \pm 9^{b}$ \\
\hline$\%$ & 88.6 & 97 & 0 & 0 & 60 & 62 & 94 & 58 & 56 & 73 \\
\hline $\begin{array}{l}\text { Intestinal } \\
\text { Digestion }\end{array}$ & $1.9 \pm 0.3^{b}$ & $2.4 \pm 0.5^{b}$ & $0.01 \pm 0.00$ & $0.05 \pm 0.01$ & $2.2 \pm 0.1^{\mathrm{c}}$ & $13 \pm 1^{d}$ & $22 \pm 8^{a}$ & $0.11 \pm 0.01^{\mathrm{c}}$ & $0.79 \pm 0.05^{\mathrm{d}}$ & $43 \pm 10^{\mathrm{ab}}$ \\
\hline \% & 89 & 87 & 100 & 100 & 58 & 47 & 164 & 32 & 40 & 81 \\
\hline
\end{tabular}


Table 2. Quantities (nmol/g DW) of anthocyanins determined in black carrot, black carrot snack and black carrot seasoning before (non-digested) and after oral, gastric and intestinal in vitro digestion. Xyl: xylosyl; Glu: glucoside; Gal: galactoside.

\begin{tabular}{|c|c|c|c|c|c|c|c|c|c|}
\hline & $\begin{array}{c}\text { Cyanidin-3- } \\
\text { xyl-gal }\end{array}$ & $\begin{array}{l}\text { Cyanidin-3-xyl- } \\
\text { coumaroyl-glu-gal }\end{array}$ & $\begin{array}{l}\text { Cyanidin-3-xyl- } \\
\text { feruloyl-glu-gal }\end{array}$ & $\begin{array}{l}\text { Cyanidin-3-xyl- } \\
\text { sinapoyl-glu-gal }\end{array}$ & $\begin{array}{l}\text { Pelargonidin-3- } \\
\text { sambiburoside }\end{array}$ & $\begin{array}{l}\text { Pelargonidin- } \\
\text { 3,5-diglu }\end{array}$ & $\begin{array}{l}\text { Cyanidin-3-xyl- } \\
\text { glu-gal }\end{array}$ & $\begin{array}{l}\text { Delphinidin- } \\
\text { 3-glu }\end{array}$ & Total \\
\hline \multicolumn{10}{|c|}{ Black Carrot } \\
\hline $\begin{array}{c}\text { Non-digested } \\
\text { Oral Digestion } \\
\%\end{array}$ & $\begin{array}{l}7 \pm 1 \\
\text { n.d. } \\
0\end{array}$ & $\begin{array}{c}15 \pm 1^{\mathrm{a}} \\
0.05 \pm 0.01^{\mathrm{b}} \\
0.3\end{array}$ & $\begin{array}{c}134 \pm 11^{\mathrm{a}} \\
0.62 \pm 0.05^{\mathrm{b}} \\
0.5\end{array}$ & $\begin{array}{c}35.7 \pm 0.9^{\mathrm{a}} \\
0.06 \pm 0.01^{\mathrm{b}} \\
0.2\end{array}$ & $\begin{array}{c}0.15 \pm 0.01 \\
\text { n.d. } \\
0\end{array}$ & $\begin{array}{c}0.14 \pm 0.01 \\
\text { n.d. } \\
0\end{array}$ & $\begin{array}{c}1.8 \pm 0.5 \\
\text { n.d. } \\
0\end{array}$ & $\begin{array}{c}0.05 \pm 0.01 \\
\text { n.d. } \\
0\end{array}$ & $\begin{array}{c}195 \pm 15^{\mathrm{a}} \\
0.7 \pm 0.1^{\mathrm{b}} \\
0.4\end{array}$ \\
\hline $\begin{array}{c}\text { Gastric } \\
\text { Digestion }\end{array}$ & n.d. & $0.009 \pm 0.001^{c}$ & $0.15 \pm 0.02^{c}$ & $0.009 \pm 0.001^{\mathrm{c}}$ & n.d. & n.d. & n.d. & n.d. & $0.2 \pm 0.0^{c}$ \\
\hline$\%$ & 0 & 0.1 & 0.1 & 0.05 & 0 & 0 & 0 & 0 & 0.1 \\
\hline $\begin{array}{l}\text { Intestinal } \\
\text { Digestion }\end{array}$ & n.d. & $0.07 \pm 0.02^{b}$ & $0.9 \pm 0.1^{b}$ & $0.05 \pm 0.02^{b}$ & n.d. & n.d. & n.d. & n.d. & $1.1 \pm 0.2^{b}$ \\
\hline$\%$ & 0 & 0.4 & 0.7 & 0.1 & 0 & 0 & 0 & 0 & 0.5 \\
\hline \multicolumn{10}{|c|}{ Black Carrot Snack } \\
\hline Non-digested & $0.28 \pm 0.02^{\mathrm{a}}$ & $0.78 \pm 0.07^{\mathrm{a}}$ & $4.76 \pm 0.01^{\mathrm{a}}$ & $1.94 \pm 0.01^{\mathrm{a}}$ & $0.009 \pm 0.001^{b}$ & $0.023 \pm 0.001^{\mathrm{b}}$ & $0.376 \pm 0.002^{\mathrm{a}}$ & $0.02 \pm 0.01^{\mathrm{a}}$ & $8.2 \pm 0.1^{\mathrm{a}}$ \\
\hline $\begin{array}{c}\text { Oral Digestion } \\
\%\end{array}$ & $\begin{array}{c}0.16 \pm 0.01 \mathrm{~b} \\
59\end{array}$ & $\begin{array}{c}0.54 \pm 0.03^{\mathrm{b}} \\
70\end{array}$ & $\begin{array}{c}3.6 \pm 0.2^{b} \\
77\end{array}$ & $\begin{array}{c}1.5 \pm 0.1^{b} \\
78\end{array}$ & $\begin{array}{c}0.012 \pm 0.001^{\mathrm{a}} \\
133\end{array}$ & $\begin{array}{c}0.01 \pm 0.01^{\mathrm{a}} \\
61\end{array}$ & $\begin{array}{c}0.21 \pm 0.02^{\mathrm{b}} \\
57\end{array}$ & $\begin{array}{c}0.01 \pm 0.01 \mathrm{~b} \\
46\end{array}$ & $\begin{array}{c}6.1 \pm 0.5^{b} \\
75\end{array}$ \\
\hline $\begin{array}{l}\text { Gastric } \\
\text { Digestion }\end{array}$ & $0.07 \pm 0.02^{c}$ & $0.24 \pm 0.02^{c}$ & $1.7 \pm 0.2^{c}$ & $0.71 \pm 0.02^{c}$ & n.d. & n.d. & $0.17 \pm 0.04^{c}$ & n.d. & $2.9 \pm 0.3^{c}$ \\
\hline$\%$ & 27 & 31 & 36 & 37 & 0 & 0 & 45 & 0 & 36 \\
\hline $\begin{array}{l}\text { Intestinal } \\
\text { Digestion }\end{array}$ & $0.036 \pm 0.001^{\mathrm{d}}$ & $0.27 \pm 0.04^{\mathrm{c}}$ & $2.2 \pm 0.2^{c}$ & $0.83 \pm 0.05^{c}$ & n.d. & n.d. & $0.15 \pm 0.02^{c}$ & n.d. & $3.5 \pm 0.3^{c}$ \\
\hline$\%$ & 13 & 35 & 47 & 43 & 0 & 0 & 41 & 0 & 43 \\
\hline \multicolumn{10}{|c|}{ Black Carrot Seasoning } \\
\hline Non-digested & $0.009 \pm 0.010^{b}$ & $0.30 \pm 0.02^{a}$ & $3.0 \pm 0.5^{b}$ & $1.6 \pm 0.4^{\mathrm{a}}$ & n.d. & n.d. & $0.06 \pm 0.02$ & $0.09 \pm 0.01$ & $5 \pm 1^{\mathrm{a}}$ \\
\hline $\begin{array}{c}\text { Oral Digestion } \\
\%\end{array}$ & $\begin{array}{c}0.03 \pm 0.02^{\mathrm{a}} \\
34\end{array}$ & $0.26 \underset{88}{ \pm 0.01}$ & $\begin{array}{l}3.7 \pm 0.3^{a} \\
124\end{array}$ & $\begin{array}{c}1.6 \pm 0.2^{\mathrm{a}} \\
101\end{array}$ & $\begin{array}{l}\text { n.d. } \\
0\end{array}$ & $\begin{array}{l}\text { n.d. } \\
0\end{array}$ & $\begin{array}{l}\text { n.d. } \\
0\end{array}$ & $\begin{array}{l}\text { n.d. } \\
0\end{array}$ & $\begin{array}{c}5.7 \pm 0.5^{\mathrm{a}} \\
109\end{array}$ \\
\hline $\begin{array}{c}\text { Gastric } \\
\text { Digestion }\end{array}$ & $0.02 \pm 0.01^{\mathrm{a}}$ & $0.14 \pm 0.01^{c}$ & $1.86 \pm 0.01^{\mathrm{c}}$ & $0.80 \pm 0.08^{b}$ & n.d. & n.d. & n.d. & n.d. & $2.8 \pm 0.1^{b}$ \\
\hline$\%$ & 21 & 48 & 62 & 48 & 0 & 0 & 0 & 0 & 54 \\
\hline $\begin{array}{l}\text { Intestinal } \\
\text { Digestion }\end{array}$ & $0.009 \pm 0.001^{\mathrm{b}}$ & $0.14 \pm 0.01^{\mathrm{c}}$ & $1.9 \pm 0.1^{c}$ & $0.84 \pm 0.02^{b}$ & n.d. & n.d. & n.d. & n.d. & $2.9 \pm 0.1^{b}$ \\
\hline $\begin{array}{l}\text { Digestion } \\
\%\end{array}$ & 10 & 46 & 65 & 51 & 0 & 0 & 0 & 0 & 57 \\
\hline
\end{tabular}

Different letters within a column denote a significant difference $(p<0.05)$ as measured by one-way ANOVA followed by the Tukey HSD post-hoc test. n.d.: not detected.

The major polyphenols still bio-accessible after the digestion process were the hydroxycinnamic acids such as 3-O-feruloylquinic acid $(4.1 \mu \mathrm{mol} / \mathrm{g}$ DW), 4-O-feruloylquinic acid $(4.5 \mu \mathrm{mol} / \mathrm{g} \mathrm{DW})$ and $p$-coumaroyl-quinic acid $(2.4 \mu \mathrm{mol} / \mathrm{g} \mathrm{DW})$. In the case of the $\mathrm{BC}$ snack and $\mathrm{BC}$ seasoning, the total amounts of polyphenols remaining after intestinal digestion were $74.5 \mu \mathrm{mol} / \mathrm{g}$ DW and $42.6 \mu \mathrm{mol} / \mathrm{g}$ DW, with a mean bio-accessibility of $69 \%$ and $81 \%$, respectively. The main polyphenols were the two isomers of $O$-feruloyl-quinic acids (Table 1). This increase during the intestinal digestion phase could be associated with the release of these compounds from the plant cell walls due to the effect of the $\mathrm{pH}(\mathrm{pH} 7)$ and the activity of bile salts and enzymes.

Significant changes in the anthocyanin content throughout the digestive process were found for all the samples analyzed, these being more marked in the black carrot (Table 2). After oral digestion, the total anthocyanin content in the black carrot dramatically decreased, $0.4 \%$ of the total anthocyanin content remaining, with only the cyanidin-based compounds acetylated with sinapic acid (cyanidin-3-xylosyl-sinapoylglucosyl-galactoside) $(0.06 \mathrm{nmol} / \mathrm{g} \mathrm{DW})$, ferulic acid (cyanidin-3-xylosyl-feruloyl-glucosylgalactoside) $(0.62 \mathrm{nmol} / \mathrm{g} \mathrm{DW})$ and coumaric acid (cyanidin-3-xylosyl-coumaroyl-glucosylgalactoside) $(0.05 \mathrm{nmol} / \mathrm{g}$ DW $)$ still present. This is in line with the premise that acetylated anthocyanins are highly stable during simulated gastrointestinal digestion, while most non-acetylated anthocyanins are degraded during this transit [42]. Due to the high impact of oral digestion on the stability of anthocyanins in black carrot, the in vitro gastric and intestinal digestion did not reveal significant changes in either in the total anthocyanin content or that of the individual anthocyanins, with a mean bio-accessibility of $0.1 \%$ and $0.5 \%$, respectively. This result is in keeping with previous studies that reported low bioaccessibility rates of anthocyanins in mulberry $(0.34 \%)$ [43], purple figs $(0-5 \%)$ [44] and sour cherry $(2.8 \%)$ [45]. It is also in accordance with the low serum and urine recovery of anthocyanins ( $<1 \%$ dose) after the consumption of black carrot concentrate [46] and purple sweet potato [47], raspberry [48], blackcurrant [49] and blueberry [50] by humans. 

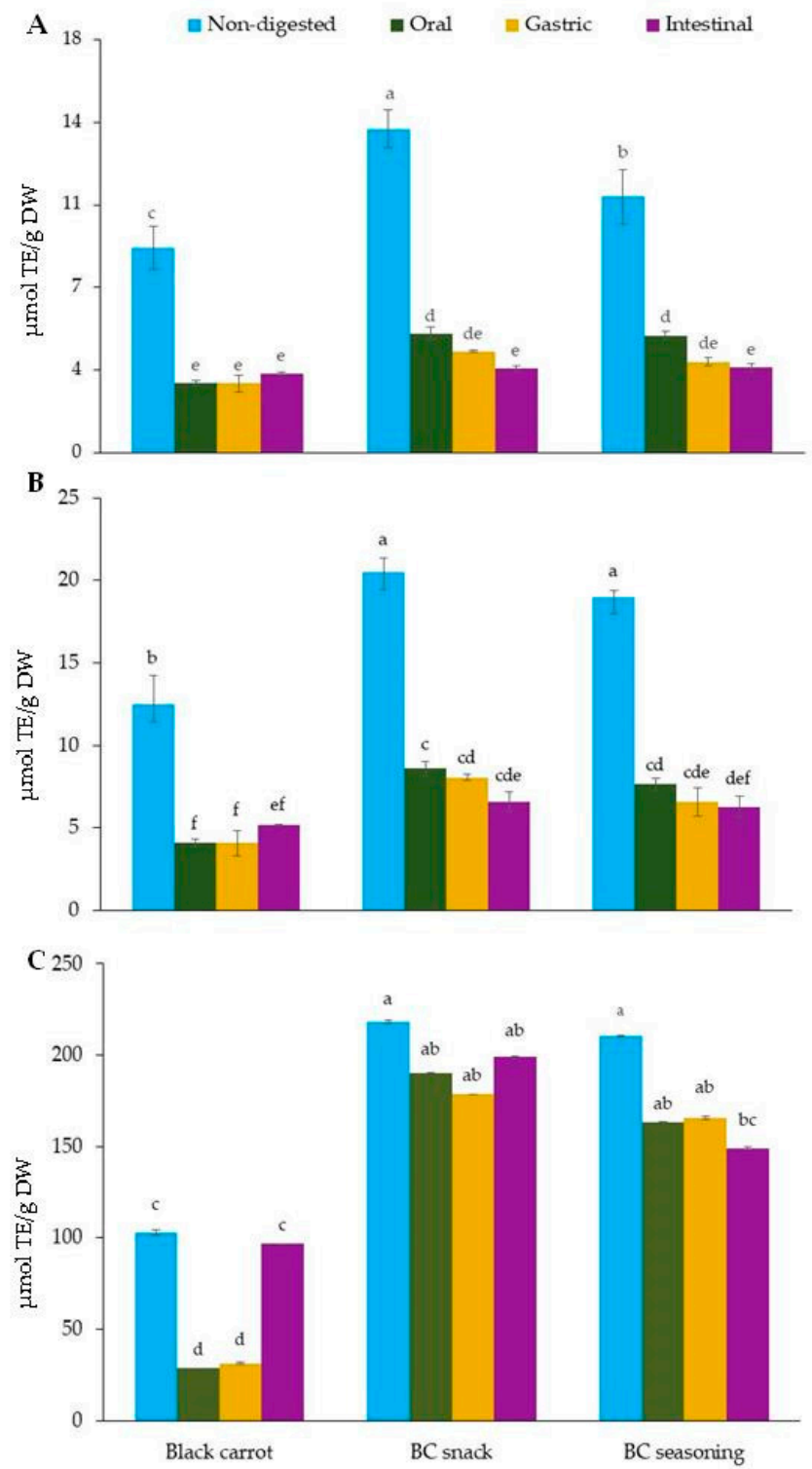

Figure 3. Panel (A-C) show the changes in the antioxidant activity of black carrot, black carrot snack and black carrot seasoning samples during the in vitro gastrointestinal digestion measured by the 2,2'-azinobis-(3-ethylbenzothiazoline-6-sulphonic acid) diammonium salt (ABTS), 1,1-diphenyl2-picryl-hydrazyl (DPPH) and oxygen radical absorbance capacity (ORAC) assays, respectively. Different lowercase letters on the top of each bar denote significant differences $(p<0.001)$ within the different products (black carrot, BC snack and BC seasoning) and the digestive steps (non-digested, oral phase, gastric phase and intestinal phase) as measured by a one-way ANOVA followed the Tukey HSD post-hoc test.

These results can be explained by the fact that anthocyanins could be metabolized to non-colored forms, oxidized or even degraded into other forms which were not detected under the conditions of this study. These results contrasted notably with the effect of the digestion process on anthocyanins in the $\mathrm{BC}$ snack and $\mathrm{BC}$ seasoning products. The elaboration process needed to obtain $\mathrm{BC}$ snack and $\mathrm{BC}$ seasoning seems to have a positive effect on black carrot anthocyanin stability. For instance, the anthocyanins in the $\mathrm{BC}$ snack and BC seasoning were more stable under oral, gastric and intestinal digestion, with an increase in the recoveries of total anthocyanins compared to those of black carrot (Table 2). In this regard, after oral digestion, the anthocyanins remaining in the BC snack and BC seasoning accounted for $75 \%$ and 109\%, respectively, cyanidin-3-xylosyl-sinapoyl- 
glucosyl-galactoside, cyanidin-3-xylosyl-coumaroyl-glucosyl-galactoside and cyanidin-3xylosyl-feruloyl-glucosyl-galactoside being the main ones in both of the products derived from black carrot. These results are consistent with previously published data showing that anthocyanins in black carrot jam and marmalade are more bioavailable [21]. One hypothesis that could explain why the stability of the anthocyanidins in black carrot during the digestive process differs to that of its derived products is that transforming black carrot into powder to create the derived products results in a decreased particle size, which enlarges the surface area available for the overall extractability of some compounds from the food matrix [51].

The gastric conditions, involving pepsin activity and low $\mathrm{pH}$, significantly decreased the concentration of total anthocyanins in both derived products, a total of $2.9 \mathrm{nmol} / \mathrm{g}$ DW (36\%) and $2.8 \mathrm{nmol} / \mathrm{g}$ DW (54\%) of anthocyanins remaining in the BC snack and BC seasoning, respectively. On the other hand, the total anthocyanin content after intestinal digestion remained stable, with mean bio-accessibilities of $43 \%$ and $57 \%$ for the BC snack and $\mathrm{BC}$ seasoning, respectively (Table 2). The most bio-accessible compounds were the three acetylated cyanidins, cyanidin-3-xylosyl-feruloyl-glucosyl-galactoside achieving the highest values followed by cyanidin-3-xylosyl-sinapoyl-glucosyl-galactoside and cyanidin3-xylosyl-coumaroyl-glucosyl-galactoside.

Similar to the results found for the polyphenol profiles, there was a significant decrease in the antioxidant activity after oral digestion compared to the non-digested samples. Figure 3 shows the effect of the in vitro digestion on the antioxidant capacity of black carrot and its derived products as measured by ABTS, DPPH and ORAC assays. After oral digestion, the antioxidant capacity did not change significantly. These results may be explained regardless of the anthocyanin content as the concentration of polyphenols is in the micromolar range while that of the anthocyanins is in the nanomolar range.

\subsection{Effect of Colonic Fermentation on Polyphenol Stability in Black Carrot and Its Derived Products}

The digested black carrot, $\mathrm{BC}$ snack and $\mathrm{BC}$ seasoning samples were incubated with human faeces for up to $48 \mathrm{~h}$ and the samples were analyzed by UHPLC-HRMS. The timecourse profiles of the black carrot polyphenol degradation are presented in Figure 4 . The compounds present after in vitro digestion in the samples of black carrot and its derived products, including 3-O-feruloylquinic acid and 4-O-feruloylquinic acid, were degraded by the colonic bacteria within $4 \mathrm{~h}$ of incubation. Meanwhile, chlorogenic acid and $p$-coumaric acid were detected in low quantities after $4 \mathrm{~h}$ of incubation, and were completely degraded after $8 \mathrm{~h}$ of fermentation (Figure 4). These results are in line with those previously reported by Ludwig et al. [48], who found that chlorogenic acids in espresso coffee were totally degraded by colonic microbiota during $6 \mathrm{~h}$ of fermentation.

The UHPLC-HRMS analysis of the faecal samples led to the identification and quantification of ten phenolic acid catabolites. Details of the identification of these catabolites are shown in Table S2 in the Supporting Information, while their time-course profiles are shown in Figure 5. All the phenolic acids were corrected for the endogenous levels of phenolic compounds found in the faecal fermentation medium.

The first breakdown product of chlorogenic acid during the faecal fermentation was considered to be 3-( $3^{\prime}, 4^{\prime}$-dihydrophenyl)propanoic acid, formed by the cleavage of the quinic acid structure and subsequent reduction of the double bond. Several bacteria in the colon have been shown to be able to catalyze such cleavage, including Escherichia coli, Bifidobacterium lactis, and Lactobacillus gasseri [52]. This catabolite reached its maximum concentration after $4 \mathrm{~h}$ for $\mathrm{BC}$ seasoning and after $8 \mathrm{~h}$ for the black carrot and $\mathrm{BC}$ snack, respectively (Figure 5). After 4 and $8 \mathrm{~h}$ of incubation, the concentration of the catabolites 3-(3-hydroxyphenyl)propanoic acid and 3,4-dihydroxyphenylacetic acid increased in the fermented medium, suggesting that they were formed from the $4^{\prime}$-dehydroxylation and decarboxylation of 3-(3',4'-dihydrophenyl)propanoic acid, respectively. The catabolite 3-(3-hydroxyphenyl)propanoic was further transformed via decarboxylation to 3'hydroxyphenylacetic acid, which appeared after $4 \mathrm{~h}$ of incubation, increasing throughout 
the faecal fermentation in the case of the BC snack, while in the black carrot and BC seasoning samples its concentration started declining after $24 \mathrm{~h}$ of incubation. In addition, small quantities of two other catabolites, 3,4-dihydroxybenzoic acid and catechol, were found in the incubation medium of the three black carrot products. They were formed via two consecutive decarboxylations of 3,4-dihydroxyphenylacetic acid (Figure 5). Taking all this into consideration, a catabolic pathway was proposed for the formation of phenolic catabolites from black carrot, BC snack and BC seasoning polyphenols during faecal fermentation (Figure 6).
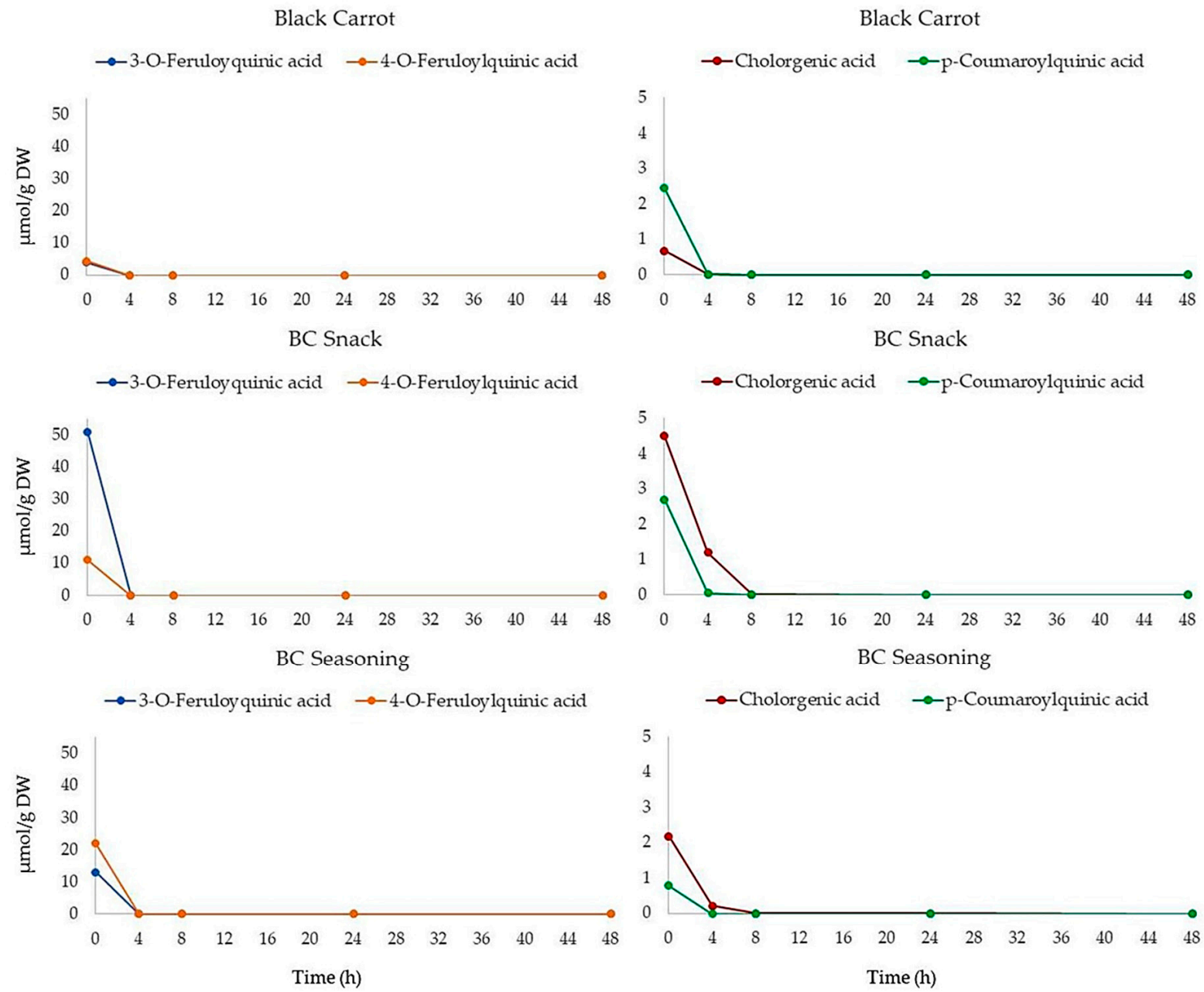

Figure 4. Degradation profiles of polyphenols in black carrot, BC snack and BC seasoning during $48 \mathrm{~h}$ of incubation with human faeces.

Overall, the total quantities of phenolic catabolites after 24 and $48 \mathrm{~h}$ of incubation were $81.6 \pm 11 \mu \mathrm{mol} / \mathrm{g}$ DW and $345 \pm 51 \mu \mathrm{mol} / \mathrm{g}$ DW for black carrot, $1236 \pm 326 \mu \mathrm{mol} / \mathrm{g}$ DW and $1519 \pm 277 \mu \mathrm{mol} / \mathrm{g}$ DW for BC snack, and $430 \pm 77 \mu \mathrm{mol} / \mathrm{g}$ DW and $0 \mu \mathrm{mol} / \mathrm{g}$ DW for BC seasoning, respectively. The phenolic acid catabolites 3-hydroxyphenylacetic acid, phenylacetic acid and 3,4-dihydroxybenzoic acid, comprising $87 \%$ of the total catabolites, were the major end products after $24 \mathrm{~h}$ of fermentation. The same catabolites, together with 3 -(4'-hydroxyphenyl)propanoic acid, represented $90 \%$ of the total catabolites after $48 \mathrm{~h}$ of incubation. In contrast, the major end product of the BC snack and BC seasoning was the catabolite 3-(4'-hydroxyphenyl)propanoic acid, which comprised 84 and $86 \%$ after $24 \mathrm{~h}$ and the $77 \%$ of the total catabolites after $48 \mathrm{~h}$, respectively. 


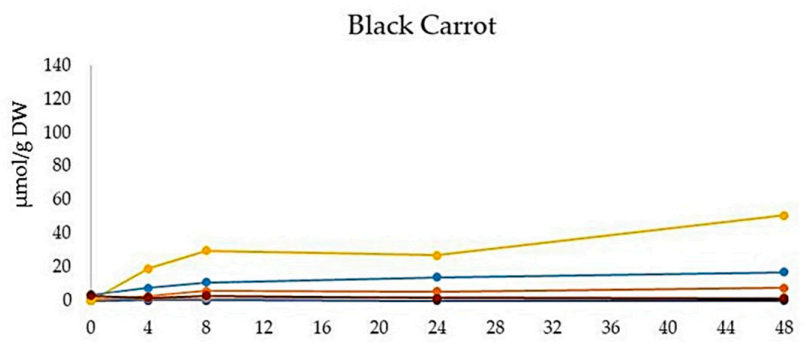

BC Snack

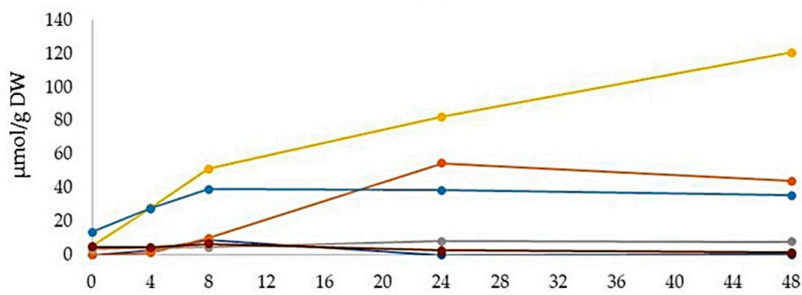

BC Seasoning

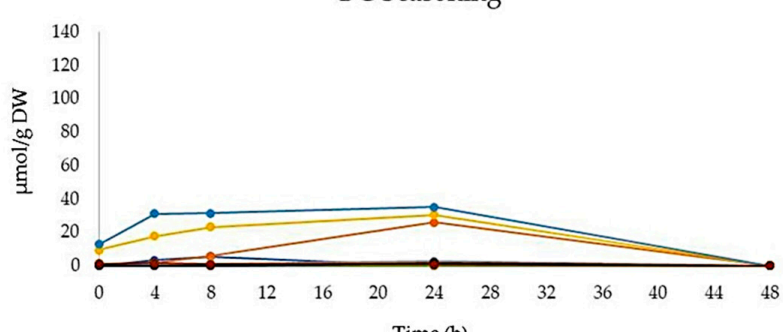

$\rightarrow 3-\left(3^{\prime}, 4^{\prime}\right.$-Dihydroxyphenyl)propanoic acid

$\rightarrow$ 3,4-Dihydroxyphenylacetic acid

$\rightarrow$ 3,4-Dihydroxybenzoic acid
Black Carrot

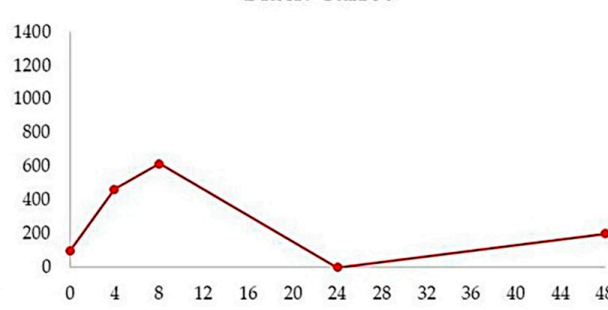

BC Snack

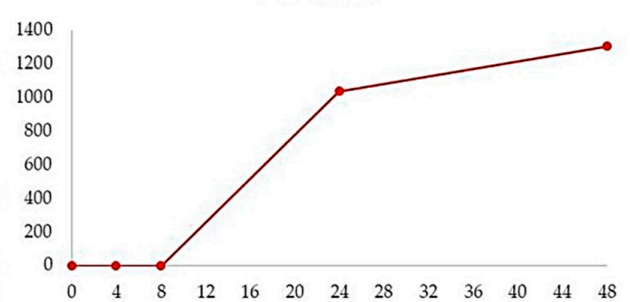

BC Seasoning

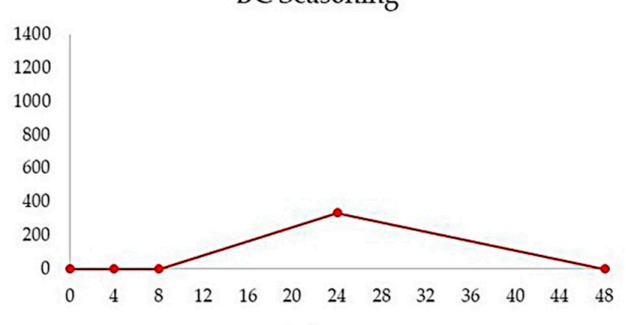
Time (h)

-0-3-(3-Hydroxyphenyl)propanoic acid

$\rightarrow$ 3-Hydroxyphenylacetic acid

$\rightarrow$-Benzene-1,3,5-triol (Catechol)

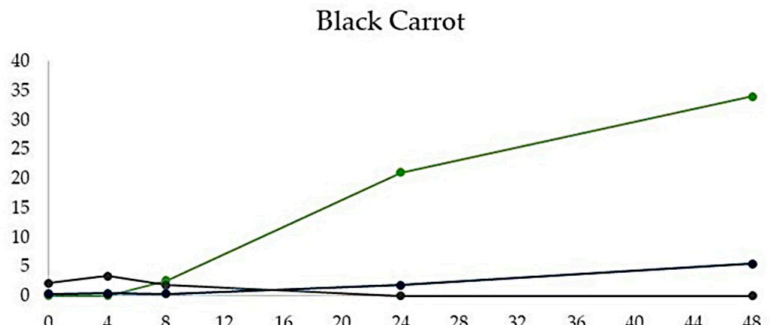

BC Snack

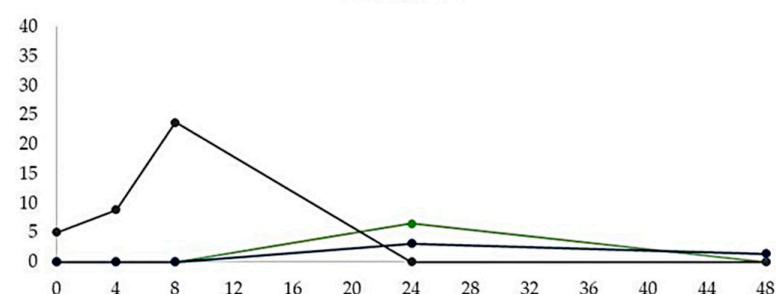

BC Seasoning

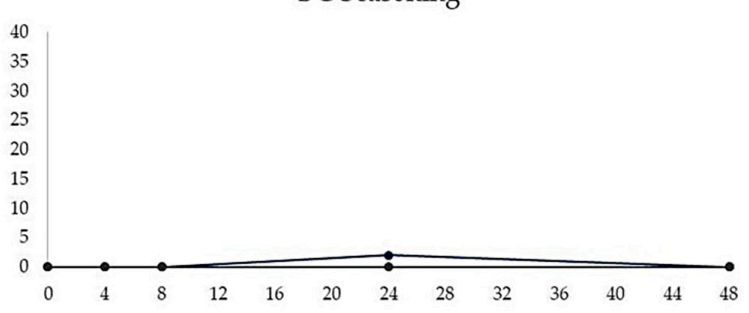

Time (h)

$\rightarrow$ Phenylacetic acid

$\rightarrow$-4-Hydroxyphenylacetic acid

$\rightarrow$-Benzoic Acid

-3-(4'-Hydroxyphenyl)propanoic acid

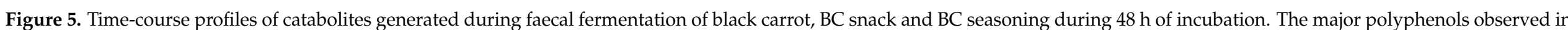

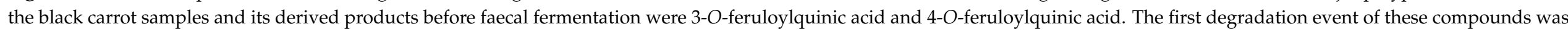

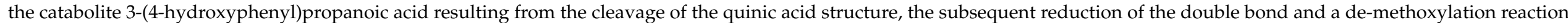

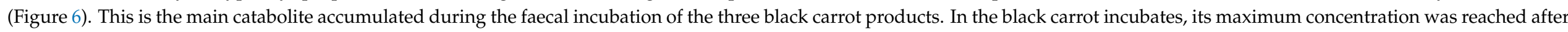

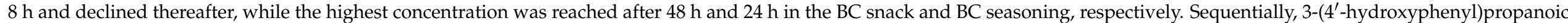

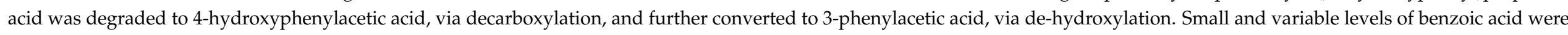
also found, indicating that it was the product of the decarboxylation of 3-phenylacetic acid (Figure 6). 


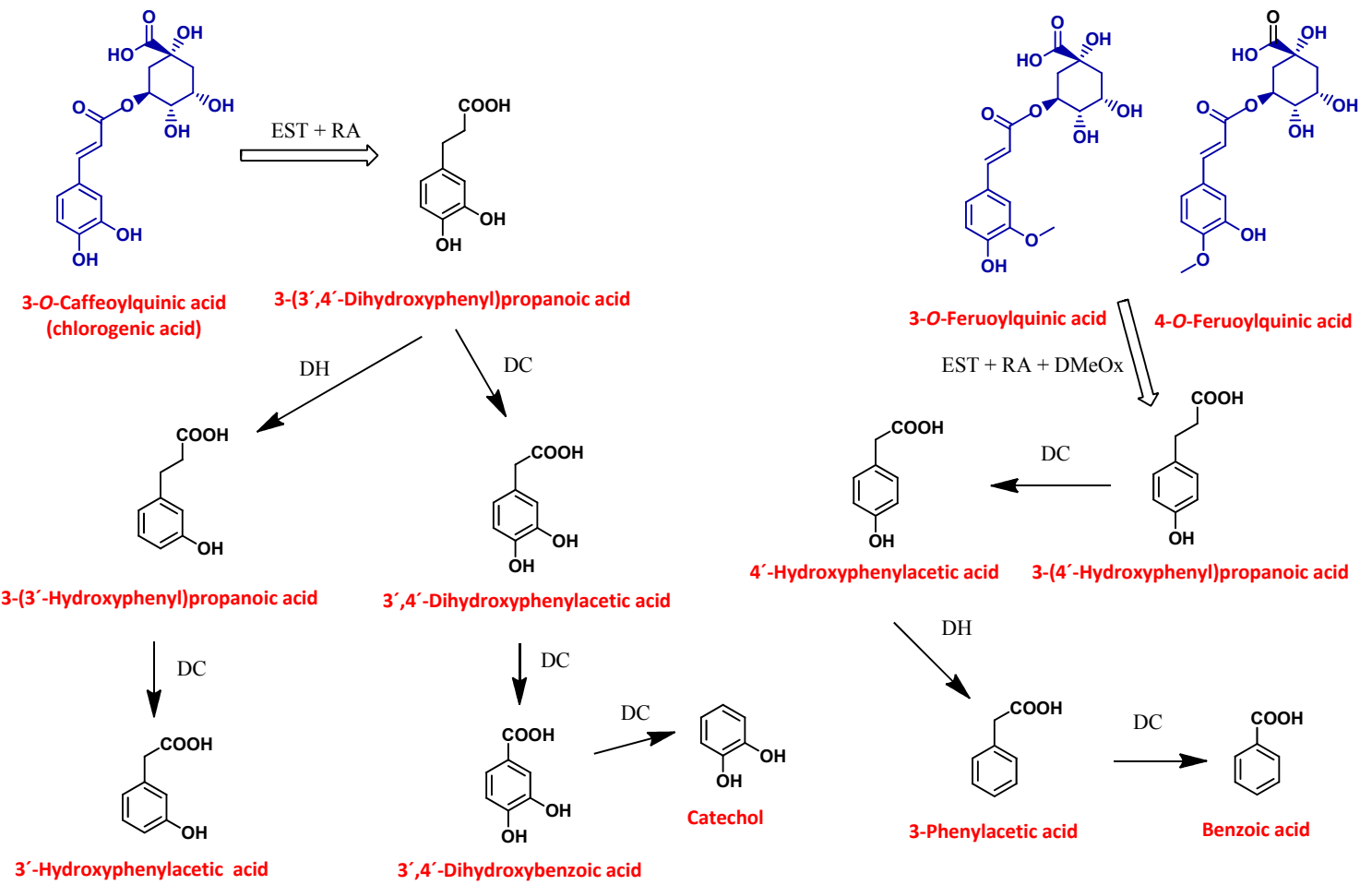

Figure 6. Catabolic pathway for black carrot polyphenols by the colonic microbiota. Compounds in blue presented before faecal fermentation and compounds in black were formed during faecal fermentation of black carrot. EST, esterase; RA, reductase; DH, dehydrogenase; DMeOx, de-methoxyesterase; DC, decarboxylation.

\section{Conclusions}

This study reports the stability and bio-accessibility of the phytochemicals in black carrot and two derived products, $\mathrm{BC}$ snack and $\mathrm{BC}$ seasoning, during in vitro digestion and faecal fermentation with human microbiota. Black carrot anthocyanins were mostly affected by the oral phase of the gastrointestinal digestion, these being more bio-accessible in the $\mathrm{BC}$ snack and $\mathrm{BC}$ seasoning. Meanwhile, hydroxycinnamic acids, which are present in significantly higher quantities compared to anthocyanins, are more stable under the digestion process. After faecal fermentation, the parent polyphenols in the black carrot samples and its derived products were completely degraded after $4 \mathrm{~h}$ of incubation, being converted to 10 phenolic acid catabolites, highlighting their extensive transformation by the human faecal microbiota. The different catabolic profiles among the black carrot and the BC snack and $\mathrm{BC}$ seasoning suggested that the stability and bio-accessibility of polyphenols depends largely on the food matrix. Nevertheless, the catabolite 3-(4'-hydroxyphenyl)propanoic acid, which is the major compound present during faecal fermentation, merits further investigation. It is potentially responsible for the health benefits at colonic level associated with the consumption of black carrot and its derived products.

Supplementary Materials: The following are available online at https:/ / www.mdpi.com/2304-815 8/10/2/457/s1, Table S1: UHPLC-HRMS characteristics of the polyphenols identified in black carrot and its derived products (black carrot snack and black carrot seasoning). Table S2. UHPLC-HRMS characteristics of phenolic acid catabolites identified in black carrot and its derived products in faecal incubates. Figure S1: Representative UHPLC-HRMS profile of polyphenols in black carrot. For peak identification see Table S1. Figure S2: Representative UHPLC-HRMS profile of anthocyanins in black carrot. For peak identification see Table S1. 
Author Contributions: Conceptualization. G.P.-C. and J.M.M.-R.; methodology. J.L.O.-D.; E.d.S.; F.J.R.-G.; software. J.L.O.-D., E.d.S., F.J.R.-G., A.M.-O., S.C.-J.; validation. J.L.O.-D.; formal analysis. E.d.S., A.M.-O.; M.S.-P.; resources. J.M.M.-R. and V.O.-S.; writing-original draft preparation. E.d.S. and G.P.-C.; writing-review and editing. G.P.-C., J.M.M.-R. and V.O.-S.; visualization. J.M.M.-R.; supervision J.M.M.-R.; project administration. G.P-C., J.M.M.-R. and V.O.-S.; funding acquisition. J.M.M.-R., and V.O.-S. All authors have read and agreed to the published version of the manuscript.

Funding: This study was funded by the Andalusian Institute of Agricultural and Fisheries Research and Training (IFAPA) and the European Rural Development Fund (ERDF. EU) through the Project "Caracterización. biodisponibilidad y potencial saludable de compuestos bioactivos de alimentos" PP.AVA.AVA2019.037. A. Moreno-Ortega is supported by a predoctoral fellowship funded by the Spanish Ministry of Education. Culture and Sport (FPU16-05881). G. Pereira-Caro is supported by a research contract funded by the project RTI2018-096703-J-I00. J.L. Ordóñez and E. de Santiago are supported by research contracts funded by the project PP.AVA.AVA2019.037. M.S.-P. was granted a research contract funded by the Andalusian Institute of Agricultural and Fisheries Research and Training (IFAPA), inside the National Youth Guarantee System (Call 2018) funded through the Agencia Estatal de Investigación (AEI).

Informed Consent Statement: Not applicable.

Acknowledgments: We thank "Esali Alimentación. S.L." for the generous gift of the materials used for the experiments (black carrots, black carrot snacks and black carrot seasoning).

Conflicts of Interest: The authors declare no conflict of interest.

\section{References}

1. Kamiloglu, S.; Van Camp, J.; Capanoglu, E. Black carrot polyphenols: Effect of processing. storage and digestion-An overview. Phytochem. Rev. 2018, 17, 379-395. [CrossRef]

2. Ahmad, T.; Cawood, M.; Iqbal, Q.; Ariño, A.; Batool, A.; Sabir Tariq, R.M.; Azam, M.; Akhtar, S. Phytochemicals in daucus carota and their health benefits-Review article. Foods 2019, 8, 424. [CrossRef] [PubMed]

3. Akhtar, S.; Rauf, A.; Imran, M.; Qamar, M.; Riaz, M.; Mubarak, M.S. Black carrot (Daucus carota L.). dietary and health promoting perspectives of its polyphenols: A review. Trends Food Sci. Technol. 2017, 66, 36-47. [CrossRef]

4. Yoo, K.S.; Bang, H.; Pike, L.; Patil, B.S.; Lee, E.J. Comparing carotene. anthocyanins. and terpenoid concentrations in selected carrot lines of different colors. Hortic. Environ. Biotechnol. 2020, 61, 385-393. [CrossRef]

5. Kumar, M.; Dahuja, A.; Sachdev, A.; Kaur, C.; Varghese, E.; Saha, S.; Sairam, K.V.S.S. Black Carrot (Daucus carota ssp.) and Black Soybean (Glycine max (L.) Merr.) Anthocyanin Extract: A Remedy to Enhance Stability and Functionality of Fruit Juices by Copigmentation. Waste Biomass Valorization 2020, 11, 99-108. [CrossRef]

6. Gajewski, M.; Szymczak, P.; Dabrowska, A.; Kret, A.; Elkner, K.; Danilcenko, H. Some aspects of nutritive and biological value of carrot cultivars with orange. yellow and purple-coloured roots. Veg. Crop. Res. Bull. 2007, 67, 149-161. [CrossRef]

7. Kammerer, D.; Carle, R.; Schieber, A. Characterization of phenolic acids in black carrots (Daucus carota ssp. sativus var. atrorubens Alef.) by high-performance liquid chromatography/ electrospray ionization mass spectrometry. Rapid Commun. Mass Spectrom. 2004, 18, 1331-1340. [CrossRef]

8. Montilla, E.C.; Arzaba, M.R.; Hillebrand, S.; Winterhalter, P. Anthocyanin composition of black carrot (Daucus carota ssp. sativus var. atrorubens Alef.) Cultivars antonina. beta sweet. deep purple. and purple haze. J. Agric. Food Chem. 2011, 59, 3385-3390. [CrossRef]

9. Schwarz, M.; Wray, V.; Winterhalter, P. Isolation and identification of novel pyranoanthocyanins from black carrot (Daucus carota L.) juice. J. Agric. Food Chem. 2004, 52, 5095-5101. [CrossRef] [PubMed]

10. Espinosa-Acosta, G.; Ramos-Jacques, A.L.; Molina, G.A.; Maya-Cornejo, J.; Esparza, R.; Hernandez-Martinez, A.R.; SánchezGonzález, I.; Estevez, M. Stability analysis of anthocyanins using alcoholic extracts from black carrot (Daucus carota ssp. Sativus var. Atrorubens alef.). Molecules 2018, 23, 2744. [CrossRef] [PubMed]

11. Mizgier, P.; Kucharska, A.Z.; Sokół-Łetowska, A.; Kolniak-Ostek, J.; Kidoń, M.; Fecka, I. Characterization of phenolic compounds and antioxidant and anti-inflammatory properties of red cabbage and purple carrot extracts. J. Funct. Foods 2016, 21, 133-146. [CrossRef]

12. Stintzing, F.C.; Stintzing, A.C.; Carle, B.; Frei, B.; Wrolstad, R.E. Color and antioxidant properties of cyanidin-based anthocyanin pigments. J. Agric. Food Chem. 2002, 50, 6172-6181. [CrossRef]

13. Algarra, M.; Fernandes, A.; Mateus, N.; de Freitas, V.; Esteves da Silva, J.C.G.; Casado, J. Anthocyanin profile and antioxidant capacity of black carrots (Daucus carota L. ssp. sativus var. atrorubens Alef.) from Cuevas Bajas. Spain. J. Food Compos. Anal. 2014, 33, 71-76. [CrossRef]

14. Kammerer, D.; Carle, R.; Schieber, A. Detection of peonidin and pelargonidin glycosides in black carrots (Daucus carota ssp. sativus var. atrorubens Alef.) by high-performance liquid chromatography/electrospray ionization mass spectrometry. Rapid Commun. Mass Spectrom. 2003, 17, 2407-2412. [CrossRef] [PubMed] 
15. Gu, C.; Howell, K.; Dunshea, F.R.; Suleria, H.A.R. LC-ESI-QTOF/MS characterisation of phenolic acids and flavonoids in polyphenol-rich fruits and vegetables and their potential antioxidant activities. Antioxidants 2019, 8, 405. [CrossRef]

16. Wojtunik-Kulesza, K.; Oniszczuk, A.; Oniszczuk, T.; Combrzyński, M.; Nowakowska, D.; Matwijczuk, A. Influence of in vitro digestion on composition. bioaccessibility and antioxidant activity of food polyphenols-A non-systematic review. Nutrients 2020, 12, 1401. [CrossRef] [PubMed]

17. Crozier, A.; Jaganath, I.B.; Clifford, M.N. Dietary phenolics: Chemistry. bioavailability and effects on health. Nat. Prod. Rep. 2009. [CrossRef]

18. Carbonell-Capella, J.M.; Buniowska, M.; Barba, F.J.; Esteve, M.J.; Frígola, A. Analytical methods for determining bioavailability and bioaccessibility of bioactive compounds from fruits and vegetables: A review. Compr. Rev. Food Sci. Food Saf. 2014, 13, 155-171. [CrossRef] [PubMed]

19. Pereira-Caro, G.; Moreno-Rojas, J.M.; Brindani, N.; Del Rio, D.; Lean, M.E.J.; Hara, Y.; Crozier, A. Bioavailability of black tea theaflavins: Absorption. metabolism. and colonic catabolism. J. Agric. Food Chem. 2017, 65, 5365-5374. [CrossRef]

20. De Santiago, E.; Pereira-Caro, G.; Moreno-Rojas, J.M.; Cid, C.; De Peña, M.P. Digestibility of (poly)phenols and antioxidant activity in raw and cooked cactus cladodes (Opuntia ficus-indica). J. Agric. Food Chem. 2018, 66, 5832-5844. [CrossRef] [PubMed]

21. Kamiloglu, S.; Pasli, A.A.; Ozcelik, B.; Van Camp, J.; Capanoglu, E. Colour retention. anthocyanin stability and antioxidant capacity in black carrot (Daucus carota) jams and marmalades: Effect of processing. storage conditions and in vitro gastrointestinal digestion. J. Funct. Foods 2015, 13, 1-10. [CrossRef]

22. Kamiloglu, S.; Capanoglu, E.; Bilen, F.D.; Gonzales, G.B.; Grootaert, C.; Van De Wiele, T.; Van Camp, J. Bioaccessibility of polyphenols from plant-processing byproducts of black carrot (Daucus carota L.). J. Agric. Food Chem. 2016, 64, $2450-2458$. [CrossRef] [PubMed]

23. Carrillo, C.; Kamiloglu, S.; Grootaert, C.; Van Camp, J.; Hendrickx, M. Co-Ingestion of black carrot and strawberry. Effects on anthocyanin stability. bioaccessibility and u ptake. Foods 2020, 9, 1595. [CrossRef]

24. Gu, C.; Suleria, H.A.R.; Dunshea, F.R.; Howell, K. Dietary lipids influence bioaccessibility of polyphenols from black carrots and affect microbial diversity under simulated gastrointestinal digestion. Antioxidants 2020, 9, 762. [CrossRef]

25. Arscott, S.A.; Tanumihardjo, S.A. Carrots of many colors provide basic nutrition and bioavailable phytochemicals acting as a functional food. Compr. Rev. Food Sci. Food Saf. 2010, 9, 223-239. [CrossRef]

26. Day, L.; Seymour, R.B.; Pitts, K.F.; Konczak, I.; Lundin, L. Incorporation of functional ingredients into foods. Trends Food Sci. Technol. 2009, 20, 388-395. [CrossRef]

27. Kamiloglu, S.; Pasli, A.A.; Ozcelik, B.; Van Camp, J.; Capanoglu, E. Influence of different processing and storage conditions on in vitro bioaccessibility of polyphenols in black carrot jams and marmalades. Food Chem. 2015, 186, 74-82. [CrossRef] [PubMed]

28. Değirmencioğlu, N.; Gurbuz, O.; Şahan, Y. The monitoring. via an in vitro digestion system. of the bioactive content of vegetable juice fermented with Saccharomyces cerevisiae and Saccharomyces boulardii. J. Food Process. Preserv. 2016, 40, 798-811. [CrossRef]

29. Kay, C.D.; Clifford, M.N.; Mena, P.; McDougall, G.J.; Andres-Lacueva, C.; Cassidy, A.; Del Rio, D.; Kuhnert, N.; Manach, C.; Pereira-Caro, G.; et al. Recommendations for standardizing nomenclature for dietary (poly)phenol catabolites. Am. J. Clin. Nutr. 2020, 112, 1051-1068. [CrossRef]

30. Moreno-Ortega, A.; Pereira-Caro, G.; Ordóñez, J.L.; Moreno-Rojas, R.; Ortíz-Somovilla, V.; Moreno-rojas, J.M. Bioaccessibility of bioactive compounds of 'fresh garlic' and 'black garlic' through in vitro gastrointestinal digestion. Foods 2020, 9, 1582. [CrossRef]

31. Ordoñez-Díaz, J.L.; Moreno-Ortega, A.; Roldán-Guerra, F.J.; Ortíz-Somovilla, V.; Moreno-Rojas, J.M.; Pereira-Caro, G. In Vitro Gastrointestinal Digestion and Colonic Catabolism of Mango (Mangifera indica L.) Pulp Polyphenols. Foods 2020, 9, 1836.

32. Re, R.; Pellegrini, N.; Proteggente, A.; Pannala, A.; Yang, M.; Rice-Evans, C. Antioxidant activity applying an improved ABTS radical cation decolorization assay. Free Radic. Biol. Med. 1999, 26, 1231-1237. [CrossRef]

33. Pereira-Caro, G.; Madrona, A.; Bravo, L.; Espartero, J.L.; Alcudia, F.; Cert, A.; Mateos, R. Antioxidant activity evaluation of alkyl hydroxytyrosyl ethers, a new class of hydroxytyrosol derivatives. Food Chem. 2009, 115, 86-91. [CrossRef]

34. Sánchez-Moreno, C.; Larrauri, J.A.; Saura-Calixto, F. A procedure to measure the antiradical efficiency of polyphenols. J. Sci. Food Agric. 1998, 76, 270-276. [CrossRef]

35. Huang, D.; Ou, B.; Hampsch-Woodill, M.; Flanagan, J.A.; Prior, R.L. High-throughput assay of oxygen radical absorbance capacity (ORAC) using a multichannel liquid handling system coupled with a microplate fluorescence reader in 96-well format. J. Agric. Food Chem. 2002, 50, 4437-4444. [CrossRef] [PubMed]

36. Hornedo-Ortega, R.; Álvarez-Fernández, M.A.; Cerezo, A.B.; Garcia-Garcia, I.; Troncoso, A.M.; Garcia-Parrilla, M.C. Influence of fermentation process on the anthocyanin composition of wine and vinegar elaborated from strawberry. J. Food Sci. 2017, 82, 364-372. [CrossRef]

37. Sumner, L.W.; Amberg, A.; Barrett, D.; Beale, M.H.; Beger, R.; Daykin, C.A.; Fan, T.W.; Fiehn, O.; Goldagre, R.; Griffin, J.L.; et al. Proposed minimum reporting standards for chemicals analysis chemical analysis Chemical Analylsis Working Group (CAWG) Metabolomics Standards Initiative (MSI). Metabolomics 2007, 3, 211-221. [CrossRef]

38. Mannino, G.; Di Stefano, V.; Laurita, A.; Pitonzo, R.; Gentile, C. Vaccinium macrocarpon (Cranberry)-based dietary supplements: Variation in mass uniformity, proanthocyanidin dosage and anthocyanidin profile demonstrates quality control standard needed. Nutrients 2020, 12, 992. [CrossRef]

39. Witrowa-Rajchert, D.; Rzaca, M. Effect of drying method on the microstructure and physical properties of dried apples. Dry. Technol. 2009, 27, 903-909. [CrossRef] 
40. Ou, B.; Huang, D.; Hampsch-Woodill, M.; Flanagan, J.A.; Deemer, E.K. Analysis of antioxidant activities of common vegetables employing oxygen radical absorbance capacity (ORAC) and ferric reducing antioxidant power (FRAP) assays. A comparative study. J. Agric. Food Chem. 2002, 50, 3122-3128. [CrossRef] [PubMed]

41. Craft, B.D.; Kerrihard, A.L.; Amarowicz, R.; Pegg, R.B. Phenol-based antioxidants and the in vitro methods used for ther assessment. Compr. Rev. Food Sci. Food Saf. 2012, 11, 148-173. [CrossRef]

42. Correa-Betanzo, J.; Allen-Vercoe, E.; McDonald, J.; Schroeter, K.; Corredig, M.; Paliyath, G. Stability and biological activity of wild blueberry (Vaccinium angustifolium) polyphenols during simulated in vitro gastrointestinal digestion. Food Chem. 2014, 165, 522-531. [CrossRef] [PubMed]

43. Liang, L.; Wu, X.; Zhao, T.; Zhao, J.; Li, F.; Zou, Y.; Yang, L. In vitro bioaccessibility and antioxidant activity of anthocyanins from mulberry (Morus atropurpurea Roxb.) following simulated gastro-intestinal digestion. Food Res. Int. 2012, 46, 76-82. [CrossRef]

44. Kamiloglu, S.; Capanoglu, E. Investigating the in vitro bioaccessibility of polyphenols in fresh and sun-dried figs (F icus carica L.). Int. J. Food Sci. Technol. 2013, 48, 2621-2629. [CrossRef]

45. Toydemir, G.; Capanoglu, E.; Kamiloglu, S.; Boyacioglu, D.; De Vos, R.C.; Hall, R.D.; Beekwilder, J. Changes in sour cherry (Prunus cerasus L.) antioxidants during nectar processing and in vitro gastrointestinal digestion. J. Funct. Foods 2013, 5, 1402-1413. [CrossRef]

46. Netzel, M.; Netzel, G.; Kammerer, D.R.; Schieber, A.; Carle, R.; Simons, L.; Konczak, I. Cancer cell antiproliferation activity and metabolism of black carrot anthocyanins. Innov. Food Sci. Emerg. Technol. 2017, 8, 365-372. [CrossRef]

47. Harada, K.; Kano, M.; Takayanagi, T.; Yamakawa, O.; Ishikawa, F. Absorption of acylated anthocyanins in rats and humans after ingesting an extract of Ipomoea batatas purple sweet potato tuber. Biosci. Biotechnol. Biochem. 2004, 68, 1500-1507. [CrossRef]

48. Ludwig, I.A.; Mena, P.; Calani, L.; Borges, G.; Pereira-Caro, G.; Bresciani, L.; Del Rio, D.; Lean, M.E.; Crozier, A. New insights into the bioavailability of red raspberry anthocyanins and ellagitannins. Free Radic. Biol. Med. 2015, 89, 758-769. [CrossRef]

49. Nielsen, I.L.; Dragsted, L.O.; Ravn-Haren, G.; Freese, R.; Rasmussen, S.E. Absorption and secretion of blackcurrant anthocyanins in humans and Watanabe heritable hyperlipidemic rabbits. J. Agric. Food Chem. 2003, 51, 2813-2820. [CrossRef]

50. Wu, X.L.; Cao, G.H.; Prior, R.L. Absorption and metabolism of anthocyanins in elderly women after consumption of elderberry or blueberry. J. Nutr. 2002, 132, 1865-1871. [CrossRef]

51. Parada, J.; Aguilera, J.M. Food microstructure affects the bioavailability of several nutrients. J. Food Sci. 2007, 72, R21-R32. [CrossRef] [PubMed]

52. Couteau, D.; McCartney, A.L.; Gibson, G.R.; Williamson, G.; Faulds, C.B. Isolation and characterization of human colonic bacteria able to hydrolyse chlorogenic acid. J. Appl. Microbiol. 2001, 90, 873-881. [CrossRef] [PubMed] 